\title{
1 Long dsRNA mediated RNA interference (dsRNAi) is antiviral in interferon 2 competent mammalian cells
}

3 SL Semple $^{1}$, RA Jacob ${ }^{2,3,4}$, K Mossman $^{2,3,4}$ and SJ DeWitte-Orr ${ }^{1}$

${ }^{1}$ Department of Health Sciences, Wilfrid Laurier University, Waterloo, ON, Canada.

${ }^{2}$ Department of Medicine, McMaster University, Hamilton, ON, Canada

${ }^{3}$ Michael G. DeGroote Institute for Infectious Disease Research, McMaster University, Hamilton, ON, Canada

${ }^{4}$ McMaster Immunology Research Centre, McMaster University, Hamilton, ON L8S 4K1, Canada

Corresponding Author: Dr. Stephanie J. DeWitte-Orr

Department of Health Sciences and Biology

Wilfred Laurier University

75 University Ave West

Waterloo, Ontario

Canada, N2L 3C5

Ph.5198840710 X4317

sdewitteorr@wlu.ca 


\begin{abstract}
In invertebrate cells, RNA interference (RNAi) acts as a powerful defense against virus infection by cleaving virally produced long dsRNA into siRNA by Dicer and loaded into RISC which can then destroy/disrupt complementary viral mRNA sequences. Comparatively in mammalian cells, the type I interferon (IFN) pathway is the cornerstone of the innate antiviral response. Although the cellular machinery for RNAi functions in mammalian cells, its role in the antiviral response remains controversial. Here we show that IFN competent mammalian cells engage in dsRNA-mediated RNAi. We found that presoaking mammalian cells with concentrations of sequence-specific dsRNA too low to induce IFN production could significantly inhibit viral replication, including SARS-CoV-2. This phenomenon was dependent on dsRNA length, was comparable in effect to transfected siRNAs, and could knockdown multiple sequences at once. Additionally, Dicer-knockout cell lines were incapable of this inhibition, confirming use of RNAi. This represents the first evidence that soaking with gene-specific dsRNA can generate viral knockdown in mammalian cells. Furthermore, demonstrating RNAi below the threshold of IFN induction has uses as a novel therapeutic platform.
\end{abstract}

Keywords: long dsRNA, pBECs, RNAi, type I interferons, viral inhibition 


\section{Introduction:}

In their historic discovery of the DNA double-helix, Watson and Crick openly stated that a similar molecule derived from ribose was "probably impossible" due to its anticipated stereochemistry (Watson \& Crick, 1953). Remarkably, just three years later, this sceptical view of double-stranded RNA (dsRNA) was disproven by Rich \& Davies (1956) when polymers of polyadenylic acid were shown to hybridize with polyuridylic acid to produce diffraction patterns typical of a helical structure. This breakthrough would revolutionize techniques in molecular biology, but this was not the only field that would be heavily influenced. Because it was known that some viruses contained only RNA, the newfound double-stranded potential provided an answer for how this nucleic acid, and hence viruses, could replicate. Scientists now realize that essentially all viruses produce long dsRNA ( $>40 \mathrm{bp}$ ) at some point during replication and that this molecule is not found in normal, healthy cells (Weber et al., 2006; Son et al., 2015). Long dsRNA acts as a pathogen associated molecular pattern (PAMP) and is capable of alerting host immune defenses to viral infection (reviewed by DeWitte-Orr and Mossman, 2010). When dsRNA binds to its complementary pattern recognition receptors (PRRs), several downstream responses activate host antiviral immunity (reviewed by Jensen and Thomsen, 2012). Interestingly, the resultant antiviral immune response can vary significantly depending on whether the host is a vertebrate or not.

When long extracellular dsRNA is detected in a vertebrate host, rapid induction of the type I interferon (IFN) pathway occurs. In this scenario, extracellular dsRNA first binds to class A scavenger receptors (SR-As) located on the cell membrane (DeWitte-Orr et al., 2010). The dsRNA is then taken up through receptor mediated endocytosis and remains in the endosome until it either binds to an endosomal PRR, called toll-like receptor 3 (TLR3, reviewed by Matsumoto et al., 2014), or is transported into the cytoplasm via the SIDT2 molecular channel (Nguyen et al., 2017). Once in the cytoplasm, the dsRNA is free to interact with cytoplasmic PRRs known as retinoic acid-inducible gene-I (RIG-I)-like receptors (RLRs) (reviewed by Rehwinkel and Gack, 2020). Regardless of their location, successful binding of dsRNA to PRRs induces a signaling cascade resulting in the production of type I IFNs, primarily IFNas and IFN $\beta$ (reviewed by Li et al., 2018). These antiviral cytokines can then act in an autocrine or paracrine manner by binding to their cognate receptors which induces expression of IFN-stimulated genes (ISGs), such as CXCL10 (reviewed by Borden et al., 2007; Cheon et al., 2014). Proteins encoded by ISGs can function to limit viral infection both directly, through inhibition of translation, and indirectly, by enhancing the adaptive immune response towards viral pathogens (reviewed by Yang and Li, 2020). This broadspectrum "antiviral state" results in a slowed metabolism and the eventual apoptosis of infected cells, hence limiting viral spread (reviewed by Fritsch and Weichhart, 2016). Importantly, the potency of the type I IFN pathway is dependent on the length of dsRNA molecules, but sequence does not appear to influence this response (Kato et al., 2008; Leonard et al., 2008; DeWitte-Orr et al., 2009; Poynter and DeWitte-Orr, 2018). As a result, the IFN pathway is recognized to induce powerful, yet non-specific, inhibition of viral replication.

In contrast, RNA interference (RNAi) is the main antiviral mechanism used when invertebrate cells encounter viral dsRNA. In the early stages of this response, RNAi appears very similar to the IFN pathway. Long extracellular dsRNA is brought into the cell either by SR-As into endosomes or transported directly into the cytoplasm via the molecular channel SID-1 (Ulvila et al., 2006; Winston et al., 2002). Similar to its mammalian homolog SIDT2, SID-1 in invertebrates transports dsRNA in a length-dependent and sequence-independent manner (Li et al., 2015). Once within the cytosol, the dsRNA is cleaved into small interfering RNAs (siRNAs) by Dicer, a dsRNA-specific RNase-III-type endonuclease (reviewed by Maillard et al., 2019). A single strand of each siRNA duplex is then bound by Argonaute (Ago), which combines with accessory proteins to form the RNA-induced silencing complex (RISC, reviewed by Maillard et al., 2019). The siRNA-loaded RISC acts to render complementary target RNAs useless, either by mediating their cleavage or by remaining bound to prevent their translation (reviewed by van den Berg 
et al., 2008). Contrary to the IFN pathway, the RNAi pathway is heavily dependent on complementarity of sequence between the siRNA and the cytosolic target RNA.

Though mammalian cells have been shown to possess all the cellular machinery needed for RNAi, it is currently believed that these organisms only use the IFN pathway to combat viral invaders (reviewed by Schuster et al., 2019). Mammalian cells can undergo RNAi with long dsRNA (dsRNAi) when IFNincompetent or when IFN competent and transfected with siRNA (Elbashir et al., 2001; Billy et al., 2001; Yang et al., 2001; Paddison et al., 2002; Maillard et al., 2013; Maillard et al., 2016). When mammalian cells have normal IFN function and are exposed to long dsRNA, it has been shown that the IFN pathway actively inhibits RNAi (Seo et al., 2013; Van der Veen et al., 2018). However, none of these studies soaked cells with long dsRNA at concentrations that were too low to induce the IFN response. Moreover, many of these studies either transfect cells with long dsRNA or use the TLR3 agonist, polyinosinic:polycytidylic acid (pIC, reviewed by Komal et al., 2021). The use of pIC is an excellent tool for understanding the IFN pathway, but it is important to note that this molecule is not the same as naturally occurring dsRNA. It has no defined length, a preparation of pIC can range from $1.5 \mathrm{~kb}$ to $8 \mathrm{~kb}$ and contains complimentary strands of inosines and cytosines, that would be not found in nature, to produce a dsRNA helix (Scadden, 2007). Thus, the results from both pIC and dsRNA transfection studies may not be indicative of the natural cellular responses to extracellular dsRNA, particularly at low concentrations. This suggests a fascinating possibility, where RNAi is the mechanism used by mammalian cells when dsRNA levels are too low to induce IFN. This sentinel activity could provide pre-emptive protection and/or clearance early in the course of infection when viral numbers are not yet high enough to warrant the costly use of the IFN pathway.

Since its discovery in 1998 by Fire and colleagues, scientists have been fascinated with the gene knockdown potential of RNAi. Yet, as described above, this sequence-specific knockdown did not seem possible in IFN-competent mammalian cells without the use of transfection agents. Moreover, the understanding of how cells respond to non-IFN inducing concentrations of dsRNA is completely absent from the literature. In the present study, we provide evidence that antiviral RNAi can be induced in mammalian cells by simply pre-soaking the cells with dsRNA at concentrations that are too low to induce IFN production. Remarkably, we were able to demonstrate this phenomenon in multiple mammalian cell types using several different dsRNA sequences to inhibit the infection of vesicular stomatitis virus expressing green fluorescent protein (VSV-GFP), as well as the human coronaviruses (CoV) HCoV-229E and SARS-CoV-2. Additionally, we reveal that this phenomenon is length-dependent and requires the presence of Dicer. Aside from the implications this work could have on developing novel antiviral/gene therapies, these results provide an explanation as to why the mammalian lineage retained all the necessary machinery for RNAi and why several mammalian viruses have devoted parts of their valuable genetic material to inhibit this pathway (Wang et al., 2006; Yang et al., 2013; Qui et al., 2020).

\section{Results:}

\subsection{The interferon response in cells soaked with long dsRNA versus pIC}

Because RNAi appears to be masked by the interferon response, it was crucial to identify which concentration of soaked dsRNA would not induce the IFN pathway. When gene expression of IFN $\beta$ and CXCL10 was measured 26h after cells were exposed to $700 \mathrm{bp}$ GFP dsRNA $(0.5 \mu \mathrm{g} / \mathrm{mL}$ and $10 \mu \mathrm{g} / \mathrm{mL})$ or $10 \mu \mathrm{g} / \mathrm{mL}$ of HMW pIC, only the pIC condition appeared to induce the IFN response (Figure 1). The THF and SNB75 cell lines were initially selected for this study to explore whether both a normalized cell line (THF) and an "abnormal" cancerous cell line (SNB75) would be capable of long dsRNAi while being IFN competent. In THF, the gene expression of IFN $\beta$ increased only in the pIC exposure condition, but due to variability this was not significantly different from the other conditions (Figure 1Ai). When SNB75 was stimulated with these dsRNA and pIC doses, only the pIC treatment was able to induce significant upregulation of IFN $\beta$ gene expression (Figure 1Bi). Because IFN $\beta$ gene expression is known to be quite rapid and short-lived, the more persistent ISG, CXCL10, was also measured. In both THF and SNB75, 
CXCL10 gene expression was only observed to significantly increase when cells were soaked with pIC (Figures 1Aii and 1Bii). Neither dsRNA concentration appeared to induce significant upregulation of IFN $\beta$ or CXCL10 when compared to the unstimulated control (Figure 1). When comparing the molar amounts, $5.1 \mathrm{nM}$ of pIC (average length of $3000 \mathrm{bp}$ ) and $21.6 \mathrm{nM}$ of $700 \mathrm{bp}$ dsRNA was added to the cells. This means that four times more dsRNA molecules were added to each cell when compared to the number of pIC molecules._Furthermore, pIC is over four times longer than the dsRNA molecules used here, so it is difficult to compare efficacy of IFN induction between these molecules. As such, pIC should only be considered a positive control in this experiment.

\subsection{Soaking with long dsRNA does not negatively impact the viability of mammalian cells}

To validate that soaking with long dsRNA does not negatively influence the health status of THF, SNB75 or MRC5, cell survival and metabolism were both measured. Following 24h exposure to a range of 700 bp GFP dsRNA concentrations, cellular metabolism was shown to significantly increase at only the highest dsRNA concentration assessed, $800 \mathrm{ng} / \mathrm{mL}$ (Figure 2A). The toxicity experiments did not use dsRNA concentrations greater than $800 \mathrm{ng} / \mathrm{mL}$ because higher concentrations were unnecessary to see RNAi effects. The significant increase in cellular metabolism at $800 \mathrm{ng} / \mathrm{mL}$ was observed in THF (Figure 2Ai), SNB75 (Figure 2Aii) and MRC5 (Figure 2Aiii) when compared to the $0 \mathrm{ng} / \mathrm{mL}$ control. Meanwhile, membrane integrity was shown to not be influenced at any of the dsRNA concentrations assessed in all three of the cell lines studied (Figure 2B). None of the dsRNA treated cells presented values significantly lower than the control cells, for both Alamar Blue and CFDA, indicating none of the dsRNAs treated were cytotoxic.

\subsection{Long dsRNAi can only be stimulated by dsRNA lengths of 400 bp or greater}

It was initially observed that pre-soaking cells with $500 \mathrm{ng} / \mathrm{mL}$ of $700 \mathrm{bp}$ GFP dsRNA for $2 \mathrm{~h}$ could stimulate protection towards VSV-GFP in both THF and SNB75 (Figure 3). Cell viability (Figure 2) and IFN induction by dsRNA (Figure 1) were both measured using 700bp long GFP dsRNA; however, the length of dsRNA capable of inducing dsRNAi required optimization. It was observed that dsRNA of 300 bp and shorter could not significantly induce knockdown of VSV-GFP in THF cells (Figure 3A). In the cancerous SNB75 cell line, the dsRNA length cut-off was less definitive as both 300 and $400 \mathrm{bp}$ did not significantly differ from either the control condition or those inducing significant knockdown (Figure 3B). The appearance of the VSV-GFP infected THF following the dsRNA treatments revealed whether knockdown was occurring as the level of fluorescence is directly related to viral load (Figure 3C).

\subsection{Mammalian cells soaked with long dsRNA of viral genes can induce viral knockdown}

Because GFP is not a naturally occurring gene found in viruses, the ability of dsRNA encoding viral gene sequences to stimulate dsRNAi was explored next. Soaking mammalian cells with viral gene specific dsRNA was shown to induce knockdown of corresponding viruses (Figure 4). When THF and SNB75 were pre-soaked with $500 \mathrm{ng} / \mathrm{mL}$ of $700 \mathrm{bp}$ dsRNA synthesized to the $\mathrm{N}$ and M protein genes of VSV, significant knockdown was observed when compared to the non-sequence matched controls of mCherry and Beta-lac (Figure 4A and 4B). Additionally, when a mixture of $250 \mathrm{ng} / \mathrm{mL} \mathrm{N}$ protein dsRNA and $250 \mathrm{ng} / \mathrm{mL} \mathrm{M}$ protein dsRNA was used to pre-soak THF cells, significant knockdown was still observed but was comparable to when only $500 \mathrm{ng} / \mathrm{mL}$ of either dsRNA was used (Figure 4A). For SNB75, this mixture preexposure was not observed to be significantly different to the control (Figure 4B). When MRC5 cells were pre-soaked with $500 \mathrm{ng} / \mathrm{mL}$ of $700 \mathrm{bp}$ dsRNA synthesized to the RdRp, N protein, M protein and spike protein genes of $\mathrm{HCoV}-229 \mathrm{E}$, significant reduction of viral particle production was observed for all exposures except for the RdRp dsRNA (Figure 4C). In Calu-3 cells, significant reduction in viral replication was observed after pre-treatment with $1000 \mathrm{ng} / \mathrm{mL}$ of SARS-CoV-2 N protein dsRNA when compared to both the virus alone control and the mis-matched mCherry dsRNA control (Figure 4D). However, no significant viral inhibition was observed when Calu-3 cells were pre-treated with $1000 \mathrm{ng} / \mathrm{mL}$ of SARS-CoV-2 M protein dsRNA (Figure 4D). 
In addition to the immortalized cell lines described above, the knockdown capability of pre-soaking cells with long dsRNA was also explored in primary pBEC cultures (Figure 5). An image of the pBECs after growth in culture for 28 days (Figure 5A). Significant knockdown of VSV-GFP was observed when pBECs were pre-treated with $500 \mathrm{ng} / \mathrm{mL}$ of dsRNA to the $\mathrm{N}$ protein of the virus when compared to the unmatched mCherry control (Figure 5B). Similar viral knockdown was also observed when the pBECs were pre-soaked with $\mathrm{HCoV}-229 \mathrm{E}$ M protein dsRNA which resulted in significant knockdown of HCoV$229 \mathrm{E}$ when compared to the mCherry control (Figure 5C). As a comparison it was also shown that soaking pBECs with $50 \mu \mathrm{g} / \mathrm{mL}$ of pIC also induced antiviral protection (Figure 5C). Indeed the level of protection provided by pIC was comparable to that provided by M protein encoding dsRNA $(p=0.1053442)$. 3.6 Soaking cells with siRNA did not induce viral knockdown

When both THF and SNB75 cells were pre-soaked with GFP siRNA, TCID 50 levels of VSV-GFP were comparable to the unstimulated control and to the mis-matched long dsRNA mCherry control (Figure 6Ai and 6Bi). Meanwhile, soaking these cells with $700 \mathrm{bp}$ GFP dsRNA was again shown to induce significant knockdown of the VSV-GFP virus (Figure 6Ai and 6Bi). This result was not due to inefficacy of the siRNA molecules as transfecting THF and SNB75 with the GFP siRNA induced significant knockdown when compared to transfection with the negative control siRNA (Figure 6Aii and 6Bii). At the timepoint tested the knockdown of VSV-GFP by GFP siRNA is similar to that by 700 bp GFP dsRNA.

\subsection{Long, synthetic combination dsRNA molecules can inhibit VSV-GFP via multiple gene knockdown}

Combination dsRNA molecules were synthesized to test whether multiple VSV genes could be knocked down when 700 bp of dsRNA contained sequences for two different viral genes. Figure 7A is a schematic of the three different combination dsRNA molecules that were synthesized for this study. When THF cells were pre-treated with $500 \mathrm{ng} / \mathrm{mL}$ of each combination dsRNA molecule and the mCherry unmatched sequence control, only the three combination molecules were able to induce significant knockdown of VSVGFP (Figure 7Bi). When measuring gene expression, only the $5^{\prime} \mathrm{N}-3^{\prime} \mathrm{M}$ molecule was able to induce significant knockdown of both the VSV N protein and M protein genes (Figure 7Bii and 7Biii). When THF cells were pre-exposed to $1000 \mathrm{ng} / \mathrm{mL}$ of the combination dsRNA molecules and the mCherry control, it was observed again that only the three combination molecules induced significant knockdown of VSVGFP (Figure 7Ci). Through pre-soaking with $1000 \mathrm{ng} / \mathrm{mL}$, only the 5'N-3'M molecule induced significant knockdown of the VSV N protein gene (Figure 7Cii), but both 5'N-3'M and the N-M Alt molecules were able to induce significant knockdown of the VSV M protein gene (Figure Ciii).

\subsection{Dicerl is a required component for the viral knockdown stimulated via cell soaking with dsRNA}

Knockdown of VSV-GFP was also obtained in the mouse MSC cell line that contains functional Dicer1 when pre-soaked with long dsRNA containing $\mathrm{N}$ protein sequence for $2 \mathrm{~h}$ prior to infection (Figure 8A). In comparison, when using the matching cell line that was Dicer1-defective, the significant decrease in viral knockdown was abolished (Figure 8B).

\section{Discussion:}

It is well established that transfecting and/or soaking vertebrate cells with long dsRNA or pIC, the IFN pathway will be stimulated (Alexopoulu et al., 2001; Hemmi et al., 2004; DeWitte-Orr et al., 2009; De Waele et al., 2017). However, little to no research has explored what the lower limit is for stimulating this IFN response through cell soaking. One study by Hägele and colleagues (2009) revealed that soaking murine cells with low concentrations of $\mathrm{pIC}(0.1-3 \mu \mathrm{g} / \mathrm{mL})$ did not stimulate protein production of IFN $\beta$ and CXCL10. However, when the cells were transfected with these low doses of pIC, a significant increase was observed for both IFN $\beta$ and CXCL10 protein production (Hägele et al., 2009). In the present study, we soaked human cells with $10 \mu \mathrm{g} / \mathrm{mL}$ of pIC and were successfully able to stimulate the gene expression of IFN $\beta$ and the ISG, CXCL10. Furthermore, we observed that the long dsRNA concentrations used in the 
used, IFN $\beta$ would be anticipated to be the primary IFN produced in response to dsRNA (Li et al., 2018). However, in glioblastoma cells, variations in IFN competence have been reported (Dick and Hubbell, 1987; Imaizumi et al., 2014; De Waele et al., 2021). When previously explored in multiple glioblastoma cell lines, pIC was shown to modestly induce IFN $\beta$ expression but significantly induced ISG (ISG15 and CXCL10) expression in some of these cultures (Wollmann et al, 2007). When taken together, the results presented here for IFN stimulation via cell soaking are comparable to what has been reported previously in the literature.

Numerous studies have shown that exposing mammalian cells to dsRNA, pIC and/or viral infection hinders cellular metabolism (reviewed by Nellimarla and Mossman, 2014). However, most of these studies explore the impact of IFN-inducing concentrations, which would be expected to reduce metabolism through induction of the antiviral state (reviewed by Fritsch and Weichart, 2016). The results presented here provide evidence that soaking cells with concentrations of dsRNA that are too low to induce IFN does influence cellular metabolism. Surprisingly, as this concentration increases (while still being too low to induce IFN), we observed a significant, increase in cellular metabolism. This could be due to low level stimulation of PAMPs by dsRNA, which has been previously observed to enhance the metabolism of immune cells (human dendritic cells)(Everts et al., 2014). The non-immune cells used in the present study can be stimulated by PAMPs and act as important sentinels for microbial infections, including those of viral origin (reviewed by Bautista-Hernández et al., 2017). Thus, soaking cells with concentrations of dsRNA that do not induce IFN can stimulate metabolic rate through activation of IFN-independent innate antiviral processes within the cell.

Unless transfection is used, the literature supports that the RNAi pathway can only be induced if the original dsRNA molecule meets a certain length requirement. This length dependence was observed in the current study but has also been shown previously in various invertebrate models. The impact of dsRNA length on RNAi efficiency was recently explored in the Colorado potato beetle (He et al., 2020). Though the beetles were exposed through ingestion of dsRNA expressing potato plants rather than soaking, it was shown that $200 \mathrm{bp}$ or greater was required to induce a robust RNAi response (He et al., 2020). A similar observation was observed when Caenorhabditis elegans was injected with long dsRNA. The length requirement for efficient knockdown was smaller in this example, at 50 to $100 \mathrm{bp}$ (Parrish et al., 2000). When explored further, it was revealed that the minimal length of dsRNA required for efficient RNA uptake by C. elegans SID-1 is 50 bp (Feinberg and Hunter, 2003; Li et al., 2015). Importantly, increasing the length of the dsRNA molecules has been shown to enhance the observed knockdown through RNAi. When soaking Drosophila S2 cells with 700 bp dsRNA, 95-99\% knockdown of the target protein was observed (Clemens et al., 2000). Further study with S2 cells revealed that there was a clear length-dependence when soaking the cells with luciferase dsRNA that was not observed when transfecting them (Saleh et al., 2006). Though significant knockdown was still observed when soaking with shorter lengths, 200 bp and greater were found to be much more effective at inducing luciferase knockdown (Saleh et al., 2006). Because there is no concern of stimulating the IFN response in invertebrate cells, concentration may also play a role that cannot be explored in IFN-competent mammalian cells. This may provide an explanation as to why the length requirement $(\sim 300-400$ bp and greater) observed in the present study was greater than those described using invertebrate cells. It is also possible that the size specificity of SID-1 includes smaller dsRNA molecules when compared to SIDT2. Additionally, because the SIDT2 channel has a higher binding affinity for dsRNA lengths ranging from 300-700 bp (Li et al., 2015), this also supports its involvement here wherein knockdown was only achievable in THF and SNB75 using dsRNA lengths of 300-400 bp and greater.

Inhibition of viral infection through pre-stimulation of the RNAi pathway is not a novel concept and has been deemed successful against multiple mammalian viruses (Gitlin et al., 2002; Wheeler et al., 2013). In fact, higher efficiency has been reported when using siRNAs that are specific for certain viral 
genes over others, similarly to what was observed in the present study when using long dsRNA. When mammalian MDCK cells were pre-transfected for $8 \mathrm{~h}$ with siRNA matching influenza viral genes of NP (nucleocapsid) and PA (component of RNA transcriptase), greater viral inhibition was observed when compared to siRNA developed for the genes of the M (matrix) and certain PB1complexes (component of RNA transcriptase, Ge et al., 2003). Moreover, when the same siRNAs were used in chicken embryos, only those that were very effective in the MDCK cells had protective effects in vivo (Ge et al., 2003). When exploring the use of siRNA for combatting COVID-19, Wu and Luo (2021) reported 50\% inhibition rates in 24h when targeting the structural Spike, N and M protein genes of SARS-CoV-2 that were overexpressed in human epithelial cells. These results have also been replicated in live animal trials. In an in vivo trial, mice were injected with lentiviruses containing siRNA that targeted either the L (polymerase) or $\mathrm{N}$ (nucleocapsid) protein of the rabies virus (RV). It was found that targeting the structural $\mathrm{N}$ protein provided $62 \%$ protection to RV infected mice while no protection was observed when the L protein was the target (Singh et al., 2014). Based on these previous results, it appears that the type of virus, and likely, variances in replication processes, play a role in which target genes have higher efficiency for RNAi knockdown. When exploring a rhabdovirus and two coronaviruses in the current study, pre-soaking with long dsRNA matching structural genes ( $N, M$ and spike proteins) was observed to be more successful than those associated with the viral transcriptional machinery (RdRp). A systematic study of each gene, including sequences within each gene, is needed in future studies to better understand what sequences are optimal targets for suppressing virus replication via dsRNAi.

As treatments that stimulate dsRNAi towards a single viral gene were successful, so simultaneous inhibition of multiple viral genes would be anticipated to enhance this effect. Combination treatments with siRNAs have shown promise in the suppression of various viral pathogens. When siRNAs that targeted both the $\mathrm{G}$ (glycoprotein) and the $\mathrm{N}$ protein genes of rabies virus was expressed in mammalian cells using a single cassette, an $87 \%$ reduction of the target virus was observed (Meshram et al., 2013). It should be noted that individual sequences offered an $85 \%$ reduction in virus titres. Similarly, when rat fibroblast cells were exposed to combination siRNAs targeting both the Immediate-early- 2 and DNA polymerase genes, a significant reduction in associated mRNAs and cytopathic effects was observed following infection with a novel rat Cytomegalovirus (Balakrishnan et al., 2020). This siRNA combination inhibition has also been explored in vivo using both rhesus monkeys and macaques. SiRNA combinations targeting multiple genes of the Zaire Ebola virus (ZEBOV) provided $66 \%$ protection in the rhesus monkeys and $100 \%$ protection in macaques to lethal doses of ZEBOV when this treatment was administered in stable nucleic acid lipid particles (Geisbert et al., 2010). Due to the greater length of long dsRNA when compared to their siRNA counterparts, it is possible to have multiple viral genes sequences present in a single molecule. In theory, this could induce knockdown of multiple viruses or multiple viral genes to inhibit infection, all without the requirement of transfection or creation of multiple dsRNA fragments. When this was explored for the first time in the present study, three combination molecules for the VSV N and M protein were shown to significantly knockdown viral titers when cells were soaked with the long dsRNA. However, qRT-PCR analysis revealed that only one of these molecules $\left(5^{\prime} \mathrm{N}-3^{\prime} \mathrm{M}\right)$ was able to significantly reduce mRNA levels of both viral genes. Though mRNA degradation is often associated with the knockdown observed during RNAi, it is important to recognize that the RISC complex can bind to complimentary mRNAs and in doing so, repress translation (reviewed by van den Berg et al., 2008). As a result, mRNA expression may not decrease but the associated protein levels would be reduced (Alemán et al., 2007; Ma et al., 2013). This provides an explanation as to why viral titers decreased, but mRNA levels were not always significantly reduced.

One of the defining mechanisms within the RNAi pathway is the cleavage of long dsRNAs into siRNAs by Dicer proteins. In both vertebrates and invertebrates, functional Dicer has been shown to be a necessity for the sequence-specific knockdown associated with RNAi (Bernstein et al., 2001; Ketting et al., 
2001; Zhang et al., 2002; Sakurai et al., 2011). We confirmed this in mammalian cells as only mouse MSCs with functional Dicer were able to induce significant knockdown of viral titers when pre-soaked with long, sequence-matched dsRNA. The role of Dicer in inhibiting viral infection has been explored in mammalian cells, but viral replication has only been modestly affected in Dicer knockouts (Matskevich and Moelling, 2007; Bogerd et al., 2014). Notably, these cells were not pre-treated with sequence-specific dsRNA prior to these infections. Based on the results of the present study, it appears that pre-soaking cells with low doses of dsRNA can provide sequence-matched protection against complimentary viral pathogens. Perhaps cells will default to RNAi when viral levels are not high enough to stimulate the IFN pathway. Aside from the data presented, this is also supported by evidence from numerous viral pathogens that specifically inhibit various components of the RNAi pathway, including Dicer. (Wang et al., 2006; Qui et al., 2020). To successfully establish infection when low levels of virus particles are present within the cell, perhaps it is critical for viruses to overcome the initial antiviral response via dsRNAi. This initial RNAi based disruption of viral mRNA could represent a constant, sentinel-like antiviral mechanism in mammalian cells. In this context mammalian cells would mount an RNAi based inhibition of viral mRNA at lower levels of circulating viral dsRNA, without initiating the energy consuming IFN response.

The results of the present study indicate several unique findings. Firstly, this is the first time in mammalian cells that RNAi has been observed through the natural uptake of sequence-specific dsRNA. This indicates that it may be possible to develop antiviral therapies involving long dsRNAs that do not involve costly transfection agents or stimulation of the damaging IFN response. Second, this viral inhibition was observed to be length-dependent, as only dsRNA that was 300-400 bp in length or greater would induce knockdown. This strongly implies a molecular channel such as SIDT2, although this was not explicitly confirmed in our study. Finally, the success of combination dsRNA constructs suggest that it may be possible to target either multiple genes within a single virus, genes originating from more than one virus or possibly those from one virus along with associated host proteins. Moreover, we were able to provide evidence that the observed viral inhibition was due to RNAi as Dicer1 knockouts could not induce this response. Confirming that pre-stimulation of RNAi in mammalian cells will induce protection against a variety of viral pathogens could have important implications for the development of novel antiviral therapies.

\section{Materials and Methods: \\ 4.1 Immortal Cell Maintenance}

The telomerase-immortalized human fibroblast cell line, THF, was received as a generous gift from Dr. Victor DeFilippis of Oregon Health and Science University. The THF cells were maintained in Dulbecco's modified eagle medium (DMEM, Corning). The human glioblastoma cell line, SNB75, was obtained as part of the NCI-60 panel. The SNB75 cells were cultured in Roswell Park Memorial Institute (RPMI)-1640 medium (Corning). Two human embryonic lung cell lines, MRC-5 (CCL-171) and HEL-299 (CCL-137) were obtained from the American Type Culture Collection (ATCC). The MRC-5 cells were propagated in Eagle's Minimum Essential Medium (EMEM, Corning) while the HEL-299 cells were cultured in DMEM (Corning). The Dicer1 positive murine mesenchymal stem cell (MSC) line (Dicer1 f/f, CRL-3220) and the Dicer1 KO MSC line (Dicer1 -/-, CRL-3221) were obtained from the ATCC. Both mouse cell lines were cultured in Minimum Essential Medium (MEM) Alpha (Gibco). The media used for the above cell lines were supplemented with $10 \%$ fetal bovine serum (FBS, Seradigm) and 1\% penicillin-streptomycin (P/S, Sigma). The lung adenocarcinoma cell line, Calu-3 (HTB-55), and the green monkey kidney epithelial cell line, Vero E6 (CRL-1586), were also obtained from ATCC. Vero E6 cells were cultured in DMEM supplemented with $10 \%$ FBS, $1 x$ L-glutamine and $1 \% \mathrm{p} / \mathrm{s}$. The Calu-3 cells were regularly cultured in MEM Alpha medium (Corning) supplemented with 10\% FBS, 1\% P/S and 1\% HEPES. All cell lines were grown in vented $\mathrm{T} 75$ flasks (Falcon) at $37^{\circ} \mathrm{C}$ with $5 \% \mathrm{CO}_{2}$. 


\subsection{Viruses}

\subsubsection{Viral Propagation}

The Indiana serotype of Vesicular Stomatitis Virus (VSV-GFP) contains a GFP gene incorporated between the viral G and L genes (Dalton and Rose, 2001). As a result, cells infected with VSV-GFP fluoresce green. In the present study, VSV-GFP was propagated on monolayers of HEL-299. Virus infections were performed in DMEM containing $10 \% \mathrm{FBS}$ and $1 \% \mathrm{P} / \mathrm{S}$ at $37^{\circ} \mathrm{C}$ with $5 \% \mathrm{CO} 2$. Viruscontaining media was cleared of cellular debris by centrifugation at 4,000 $\mathrm{g}$ for $4 \mathrm{~min}$ followed by filtration through a $0.45 \mu \mathrm{m}$ filter. The filtered supernatant was aliquoted and stored at $-80^{\circ} \mathrm{C}$ until ready to be quantified.

HCoV-229E was purchased from ATCC (VR-740) and subsequently propagated on monolayers of MRC5 cells. Viral infections were performed in EMEM medium containing $2 \% \mathrm{FBS}$ and $1 \% \mathrm{P} / \mathrm{S}$ at $37^{\circ} \mathrm{C}$ with $5 \% \mathrm{CO}_{2}$. After two days, virus-containing media was cleared at $4,000 \mathrm{~g}$ and filtered through a 0.45 $\mu \mathrm{M}$ filter. The filtered supernatant was aliquoted and stored at $-80^{\circ} \mathrm{C}$ until ready to be quantified. The second $\mathrm{HCoV}$ used in this study, SARS-CoV-2 isolate SB3, was propagated on Vero E6 cells as previously described by Banerjee et al. (2020). All SARS-CoV-2 infections were performed at a designated BSL-3 lab in accordance with guidelines from McMaster University.

\subsubsection{Tissue Culture Infectious Dose (TCID50)}

The cell lines described above for viral propagation were seeded in 96-well plates $\left(1.5 \times 10^{4}\right.$ cells/well $)$ and were used to titer their respective viruses by $\mathrm{TCID}_{50}$. Following overnight adherence, all wells received $100 \mu \mathrm{L}$ of fresh 10\% FBS media. For VSV-GFP, the supernatants of interest were serially diluted 1:5 in basal DMEM media. With HCoV-229E, the supernatants of interest were serially diluted 1:10 in basal EMEM media. For each sample dilution, $10 \mu \mathrm{L}$ was added to eight wells of a 96-well plate for VSV-GFP and six wells for $\mathrm{HCoV}-229 \mathrm{E}$. Plates were then either incubated at $37^{\circ} \mathrm{C}$ (VSV-GFP) or $33^{\circ} \mathrm{C}(\mathrm{HCoV}-$ $229 \mathrm{E}$ ) at $5 \% \mathrm{CO}_{2}$. At three (VSV-GFP) or seven (HCoV-229E) days post-infection, wells were scored by the presence of cytopathic effects (CPE) and viral titers were calculated using the Reed and Meunsch method to obtain the TCID50/mL (Reed \& Muensch, 1938).

\subsection{Synthesis of dsRNA molecules}

Genes of interest were amplified using forward and reverse primers that contained $\mathrm{T} 7$ promoters. The primer sets and their associated templates are outlined in Table 1. The DNA products were amplified by PCR using $10 \mathrm{ng}$ of appropriate template (Table 1), 2X GOTaq colorless master mix (Promega), $0.5 \mu \mathrm{M}$ of both forward and reverse primers (Table 1, Sigma Aldrich), and nuclease free water to a final volume of $50 \mu \mathrm{L}$. The following protocol was carried out in a Bio-Rad T100 thermocycler: $98^{\circ} \mathrm{C}-5$ min, 34 cycles of $98^{\circ} \mathrm{C}-10 \mathrm{~s}, 50^{\circ} \mathrm{C}-10 \mathrm{~s}, 72^{\circ} \mathrm{C}-50 \mathrm{~s}$, followed by $72^{\circ} \mathrm{C}-5 \mathrm{~min}$. The resulting DNA amplicons with $\mathrm{T} 7$ promoters on both DNA strands were purified using a QIAquick PCR purification kit (Qiagen). The purified product was then used in the MEGAScript RNAi Kit (Invitrogen) as per the manufacturer's instructions to produce dsRNA. To confirm primer specificity, $100 \mathrm{ng}$ of all PCR amplicons and the final dsRNA product were separated on $1 \%$ agarose gels containing $1 \%$ GelGreen (Biotium Inc.).

\subsection{Testing for induction of the antiviral interferon response \\ 4.4.1 RNA Extraction}

In a 24-well plate, either THF or SNB75 were seeded at a density of $5.0 \times 10^{4}$ cells/well. Following overnight adherence, the media was replaced before exposure to either a DPBS control, $0.5 \mu \mathrm{g} / \mathrm{mL}$ of long dsRNA, $10 \mu \mathrm{g} / \mathrm{mL}$ of long dsRNA, or $10 \mu \mathrm{g} / \mathrm{mL}$ of high molecular weight (HMW) polyinosinic:polycytidylic acid (pIC) all diluted in full growth media. Cells were exposed to these treatments for $26 \mathrm{~h}$ before the media was removed and the test wells were washed once with DPBS. Cells were then collected in TRIzol (Invitrogen) and total RNA was extracted according to the manufacturer's 
instructions. RNA was then treated with Turbo DNA-free ${ }^{\mathrm{TM}}$ Kit (Invitrogen) to remove any contaminating genomic DNA. Complementary DNA (cDNA) was synthesized from $500 \mathrm{ng}$ of purified RNA using the iScript ${ }^{\mathrm{TM}}$ cDNA Synthesis Kit (Bio-Rad) following protocols provided by the manufacturer. 4.4.2 $q R T-P C R$

The expression of IFN related genes (IFN $\beta$ and CXCL10) was measured by quantitative real-time polymerase chain reaction (qRT-PCR). IFN $\beta$ was chosen because it is frequently the first type I IFN induced following dsRNA treatment, particularly in fibroblasts (Bolivar et al., 2018; Li et al., 2018). CXCL10 was chosen as the representative ISG because its expression levels are very high in the presence of IFNs (Buttmann et al., 2007; Antonelli et al., 2010). All PCR reactions contained: $2 \mu \mathrm{L}$ of diluted cDNA, 2x SsoFast EvaGreen Supermix (Bio-Rad), $0.2 \mathrm{mM}$ of forward primer (Sigma Aldrich), $0.2 \mathrm{mM}$ of reverse primer (Sigma Aldrich) and nuclease-free water to a total volume of $10 \mu \mathrm{L}$ (Fisher Scientific). The sequences and accession number for each primer set are outlined in Table 2. The qRT-PCR reactions were performed using the CFX Connect Real-Time PCR Detection System (Bio-Rad). The program used for all reactions was: $98^{\circ} \mathrm{C}$ denaturation for $3 \mathrm{~min}$, followed by 40 cycles of $98^{\circ} \mathrm{C}$ for $5 \mathrm{sec}, 55^{\circ} \mathrm{C}$ for 10 sec, and $95^{\circ} \mathrm{C}$ for $10 \mathrm{sec}$. A melting curve was completed from $65^{\circ} \mathrm{C}$ to $95^{\circ} \mathrm{C}$ with a read every $5 \mathrm{sec}$. Product specificity was determined through single PCR melting peaks. All qRT-PCR data was analyzed using the $\Delta \Delta \mathrm{Ct}$ method and is presented as the average of four experimental replicates with the standard error of the mean (SEM). Specifically, gene expression was normalized to the housekeeping gene ( $\beta$ actin) and presented as fold changes over the control group.

\subsection{Cell viability to dsRNA}

To determine whether different dsRNA concentrations could influence the survival of THF, MRC5 and SNB75, two fluorescent indicator dyes, Alamar Blue (AB, Invitrogen) and 5-carboxyfluorescein diacetate acetoxymethyl ester (CFDA-AM, Invitrogen), were used. Together these dyes provide an excellent indication of cell viability as both cellular metabolism (AB) and membrane integrity (CFDA-AM) are measured (Dayeh et al., 2003). THF and SNB75 cells were seeded at a density of 1 x $10^{4}$ cells/well in a 96well tissue culture plate and allowed to adhere overnight at $37^{\circ} \mathrm{C}$ with $5 \% \mathrm{CO}_{2}$. All cell monolayers were washed once with DPBS and then treated in eight-fold with a doubling dilution of dsRNA ranging from $800 \mathrm{ng} / \mathrm{mL}$ to $3.13 \mathrm{ng} / \mathrm{mL}$ for $24 \mathrm{~h}$ at $37^{\circ} \mathrm{C}$ with $5 \% \mathrm{CO}_{2}$ in normal growth media. Following incubation, each well was washed twice with DPBS before exposure to AB and CFDA-AM as described previously by Dayeh et al. (2003). Because two fluorescent dyes were used to test cell viability, the 96-well plate was read at an excitation of $530 \mathrm{~nm}$ and an emission of $590 \mathrm{~nm}$ for $\mathrm{AB}$ as well as an excitation of $485 \mathrm{~nm}$ and an emission of $528 \mathrm{~nm}$ for CFDA-AM. The reads were completed using a Synergy HT plate reader (BioTek Instruments). For each cell line analyzed, three independent experiments were performed.

\subsection{Stimulating viral inhibition via soaking with low doses of dsRNA}

THF and SNB75 cells were seeded at a density of $5.0 \times 10^{4}$ cells/well in a 24 -well plate (Falcon). Following overnight adherence, the media in all test wells was changed to fresh media. The cells were then pre-treated for $2 \mathrm{~h}$ with either a DPBS control, $500 \mathrm{ng} / \mathrm{mL}$ of $700 \mathrm{bp}$ GFP dsRNA, or $500 \mathrm{ng} / \mathrm{mL}$ of $700 \mathrm{bp}$ mCherry dsRNA at $37^{\circ} \mathrm{C}$ with $5 \% \mathrm{CO}_{2}$. Pre-treatment for $2 \mathrm{~h}$ was selected after completing a time course experiment to determine the optimal amount of time to pre-treat cells with dsRNA to induce viral knockdown (supplementary figure S1). All test wells were then exposed to VSV-GFP at a multiplicity of infection (MOI) of 0.1 and allowed to incubate for $24 \mathrm{~h}$ at $37^{\circ} \mathrm{C}$ with $5 \% \mathrm{CO} 2$ before supernatants were collected for TCID50 quantification as described above.

\subsection{Elucidating the role of sequence length in $d s R N A i$}


To explore the impact that the dsRNA sequence length had on the observed viral knockdown, dsRNA was synthesized to GFP that ranged in size from $200 \mathrm{bp}$ to $700 \mathrm{bp}$ and tested for ability to induce knockdown. THF or SNB75 were seeded in a 24-well plate at a density of $5.0 \times 10^{4}$ cells/well. Following overnight adherence followed by a media change, the cells were pre-treated for $2 \mathrm{~h}$ with either a DPBS control, $500 \mathrm{ng} / \mathrm{mL}$ of mCherry dsRNA, or $500 \mathrm{ng} / \mathrm{mL}$ of GFP dsRNA at lengths of $200 \mathrm{bp}, 300 \mathrm{bp}, 400$ bp, $500 \mathrm{bp}, 600 \mathrm{bp}$ and $700 \mathrm{bp}$ at $37^{\circ} \mathrm{C}$ with $5 \% \mathrm{CO}_{2}$. All test wells were then exposed to VSV-GFP at an MOI of 0.1 and allowed to incubate for $24 \mathrm{~h}$ at $37^{\circ} \mathrm{C}$ with $5 \% \mathrm{CO} 2$ before supernatants were collected for TCID50 quantification as described above.

528

529

530

531

\subsection{Use of viral genes for dsRNAi}

\subsubsection{VSV-GFP}

DsRNA was synthesized to the VSV viral genes of $\mathrm{N}$ protein and $\mathrm{M}$ protein as described above. Either THF or SNB75 were seeded in a 24 -well plate at a density of $5.0 \times 10^{4}$ cells $/$ well. Following overnight adherence, the media in all test wells was changed to fresh media. The cells were then pretreated for $2 \mathrm{~h}$ with either a DPBS control, $500 \mathrm{ng} / \mathrm{mL}$ of VSV N protein dsRNA, $500 \mathrm{ng} / \mathrm{mL}$ of VSV M protein dsRNA, $500 \mathrm{ng} / \mathrm{mL}$ of mCherry dsRNA or a combination of $250 \mathrm{ng} / \mathrm{mL}$ of VSV N protein and $250 \mathrm{ng} / \mathrm{mL}$ of VSV M protein ( $500 \mathrm{ng} / \mathrm{mL}$ total of dsRNA) at $37^{\circ} \mathrm{C}$ with $5 \% \mathrm{CO}_{2}$. All test wells were then exposed to VSV-GFP at an MOI of 0.1 and allowed to incubate for $24 \mathrm{~h}$ at $37^{\circ} \mathrm{C}$ with $5 \% \mathrm{CO}_{2}$ before supernatants were collected for TCID50 quantification as described above.

4.8.2 HCoV-229E

DsRNA was synthesized for HCoV-229E viral genes of RdRp, Spike protein, N protein and M protein as described above. MRC5 cells were seeded in a 24 -well plate at a density of $7.5 \times 10^{4}$ cells/well. Following overnight adherence, the media in all test wells was changed to fresh media. The cells were then pre-treated for $2 \mathrm{~h}$ with either a DPBS control, $500 \mathrm{ng} / \mathrm{mL}$ of $229 \mathrm{E}$ RdRp, $500 \mathrm{ng} / \mathrm{mL}$ of $229 \mathrm{E}$ Spike protein, $500 \mathrm{ng} / \mathrm{mL}$ of $229 \mathrm{E} \mathrm{N}$ protein dsRNA, $500 \mathrm{ng} / \mathrm{mL}$ of $229 \mathrm{E}$ M protein dsRNA or $500 \mathrm{ng} / \mathrm{mL}$ of mCherry dsRNA at $37^{\circ} \mathrm{C}$ with $5 \% \mathrm{CO}_{2}$. All test wells were then exposed to $\mathrm{HCoV}-229 \mathrm{E}$ at an MOI of 0.02 and allowed to incubate for $24 \mathrm{~h}$ at $37^{\circ} \mathrm{C}$ with $5 \% \mathrm{CO}_{2}$ before supernatants were collected for TCID50 quantification as described above.

\subsubsection{SARS-CoV-2}

DsRNA was synthesized for the SARS-CoV-2 viral genes, $\mathrm{N}$ protein and $\mathrm{M}$ protein, as described above. Calu-3 cells were seeded in a 12 -well plate at a density of $2.0 \times 10^{5}$ cells/well. Two days later, the media was replaced with fresh media. The cells were then pretreated for $2 \mathrm{~h}$ with either $1000 \mathrm{ng} / \mathrm{mL}$ of mCherry dsRNA control, $1000 \mathrm{ng} / \mathrm{mL}$ of SARS-CoV-2 M protein dsRNA or $1000 \mathrm{ng} / \mathrm{mL}$ of SARS-CoV$2 \mathrm{~N}$ protein dsRNA at $37^{\circ} \mathrm{C}$ with $5 \% \mathrm{CO}_{2}$. Following pre-treatment, the cells were exposed to SARSCoV-2 at an MOI of 1.0 for $1 \mathrm{~h}$, washed twice with sterile 1x PBS, and the dsRNA added back to the appropriate wells. After 24h, total RNA isolation was performed using the RNeasy Mini Kit (Qiagen) according to the manufacturer's protocol. SARS-CoV-2 specific genome levels were measured by qPCR using SsoFast EvaGreen supermix (Bio-Rad) according to manufacturer's protocol.

\section{9 dsRNAi in human primary Bronchial/Tracheal Epithelial Cells (pBECs)}

\subsubsection{Culture of human pBECS}

Normal human primary bronchial/tracheal epithelial cells (pBECs) were purchased from ATCC (PCS-300-010). The pBECs were transferred to six T25 flasks containing complete Airway Epithelial Cell medium (ATCC) and cells were incubated at $37^{\circ} \mathrm{C}$ with $5 \% \mathrm{CO}_{2}$ until they reached approximately $80 \%$ confluence. Cells were then detached using $0.25 \%$ trypsin (Gibco) and transferred to $1 \mu \mathrm{m}$ transwell permeable supports (Falcon) in a 24 -well plate at a density of $3.3 \times 10^{4}$ cells/insert ( $200 \mu \mathrm{L}$ per insert). The basolateral side received $700 \mu \mathrm{L}$ of complete Airway Epithelial Cell medium. Media changes were 
made every $2 \mathrm{~d}$ with the apical layer receiving $200 \mu \mathrm{L}$ and the basolateral layer receiving $700 \mu \mathrm{L}$. Once the cells reached $100 \%$ confluence, the media was aspirated from the transwell which was then transported to a new 24-well plate and $600 \mu \mathrm{L}$ of PneumaCult ${ }^{\mathrm{TM}}$ ALI Maintenance medium (STEMCELL Technologies) was added to the basolateral side. Cells were left to grow for $28 \mathrm{~d}$ with basolateral media changes occurring every $2 \mathrm{~d}$. After approximately $7 \mathrm{~d}$, apical washes using $200 \mu \mathrm{L}$ of DPBS were performed every week to clear the cells of mucus production. After $28 \mathrm{~d}$ the cells were used for experiments.

\subsubsection{Soaking with long dsRNA}

Transwells containing the 28-day cultured pBECs were washed once by incubation with with 200 well contained $600 \mu \mathrm{L}$ of fresh PneumaCult ${ }^{\mathrm{TM}}$-ALI Complete Base Medium (STEMCELL Technologies) for the basolateral side. The DPBS was removed from the apical side of the test transwells and were then exposed to either media alone, $500 \mathrm{ng} / \mathrm{mL}$ of dsRNA (VSV N protein, $\mathrm{HCoV}-229 \mathrm{E}$ M protein or mCherry as a control) or $50 \mu \mathrm{g} / \mathrm{mL}$ of pIC for $2 \mathrm{~h}$ at $37^{\circ} \mathrm{C}$ with $5 \% \mathrm{CO}_{2}$. Following the $2 \mathrm{~h}$ incubation, appropriate test wells were exposed to either VSV-GFP $(\mathrm{MOI}=0.1)$ or HCoV-229E $(\mathrm{MOI}=0.1)$ and incubated for $24 \mathrm{~h}$ before the supernatants were collected and the TCID50 was quantified as described above.

\subsection{Soaking versus transfection with siRNA}

In order to directly compare the effects of soaking with long dsRNA or siRNA on virus inhibition, THF and SNB75 cells were seeded in 24-well plates at a density of $5.0 \times 10^{4}$ cells/well. Following overnight adherence and a fresh media change, cells were exposed to either a DPBS control, $2 \mathrm{nM}$ of $700 \mathrm{bp}$ GFP dsRNA, $2 \mathrm{nM}$ of GFP Silencer ${ }^{\circledR}$ siRNA (Ambion) or $2 \mathrm{nM}$ of the negative control Silencer ${ }^{\circledR}$ siRNA $^{-1}$ (Ambion) for $2 \mathrm{~h}$ at $37^{\circ} \mathrm{C}$ with $5 \% \mathrm{CO}_{2}$. Cells were exposed to nanomolar concentrations (equivalent to 500 $\mathrm{ng} / \mathrm{mL}$ of $700 \mathrm{bp}$ dsRNA) to ensure that the same number of dsRNA and siRNA molecules were added in each treatment group. Following this incubation, wells were exposed to VSV-GFP at an MOI of 0.1 and incubated for $24 \mathrm{~h}$ at $37^{\circ} \mathrm{C}$ with $5 \% \mathrm{CO} 2$ before supernatants were collected for TCID50 quantification as described above.

For validation that the siRNA molecules were functional and capable of inducing knockdown, the siRNA molecules were transfected into SNB75 and THF cells and subsequent viral numbers were quantified. THF and SNB75 cells were seeded 24-well plates at a density of $5.0 \times 10^{4}$ cells/well. Following

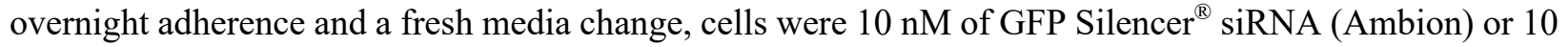
$\mathrm{nM}$ of the negative control Silencer ${ }^{\mathbb{R}}$ siRNA (Ambion) was transfected into the cells using Lipofectamine RNAiMAX (Invitrogen). Cells were transfected with 10nM siRNA as recommended by the manufacturer. Following a $24 \mathrm{~h}$ incubation at $37^{\circ} \mathrm{C}$ with $5 \% \mathrm{CO}_{2}$, wells were washed twice with DPBS and then exposed to VSV-GFP at an MOI of 0.1 and incubated for $24 \mathrm{~h}$ at $37^{\circ} \mathrm{C}$ with $5 \% \mathrm{CO} 2$ before supernatants were collected and the TCID50 was quantified as described above.

\subsection{Inducing viral inhibition using combination dsRNA molecules that target multiple viral genes}

To determine whether combination dsRNA could induce viral knockdown via inhibition of multiple viral genes at once, THF cells were seeded at a density of $5.0 \times 10^{4}$ cells/well in a 24 -well plate. Following overnight adherence, the media in all test wells was changed to fresh media. The cells were then pre-treated for $2 \mathrm{~h}$ with either a DPBS control, $500 \mathrm{ng} / \mathrm{mL}$ of 5' $\mathrm{N}-3^{\prime} \mathrm{M}$ (first $350 \mathrm{bp}$ are VSV N protein and last $350 \mathrm{bp}$ are VSV M protein), $500 \mathrm{ng} / \mathrm{mL}$ of 5'M-3'N (first $350 \mathrm{bp}$ are VSV M protein and last $350 \mathrm{bp}$ are VSV N protein), $500 \mathrm{ng} / \mathrm{mL}$ of N-M Alt (50 bp of VSV N protein and $50 \mathrm{bp}$ of VSV M protein in alternating fashion for $700 \mathrm{bp}$ ), or $500 \mathrm{ng} / \mathrm{mL}$ mCherry dsRNA at $37^{\circ} \mathrm{C}$ with $5 \% \mathrm{CO} 2$. All test wells were then exposed to VSV-GFP at an MOI of 0.1 and allowed to incubate for $24 \mathrm{~h}$ at $37^{\circ} \mathrm{C}$ with $5 \% \mathrm{CO}_{2}$ before supernatants were collected for TCID50 quantification as described above. The cell monolayers were collected in Trizol so 
that total RNA could be extracted and cDNA was synthesized as described above in section 2.4. The expression of VSV genes ( $M$ and N protein) was measured by qRT-PCR using the same method as outlined above in section 2.4. The sequences and accession number for the primer sets used here are outlined in Table 2. The VSV gene expression of cells exposed to the 5'M-3'N molecule was not measured due to the small size of the M protein gene which made it impossible to develop qPCR primers that did not amplify a region of the M-N dsRNA that was used to soak the cells.

\subsection{Dicer knockout studies}

For successful knockdown, the RNAi pathway requires the use of Dicer to cleave viral RNAs into siRNAs. To provide evidence that the knockdown observed here was due to RNAi, a Dicer1 knockout mouse MSC cell line (Dicer1 -/-) was used along with its corresponding functional Dicer1 cell line (Dicer1 $\mathrm{f} / \mathrm{f}$ ). For each experiment, both the knockout and functional Dicer MSC cell lines were seeded at a density of $5.0 \times 10^{4}$ cells/well in a 24 -well plate. Following overnight adherence, the media in all test wells was changed to fresh media. Both cell types were then pre-soaked for $2 \mathrm{~h}$ with either a DPBS control, $500 \mathrm{ng} / \mathrm{mL}$ of VSV N protein dsRNA, or $500 \mathrm{ng} / \mathrm{mL}$ of mCherry dsRNA at $37^{\circ} \mathrm{C}$ with $5 \% \mathrm{CO}_{2}$. All test wells were then exposed to VSV-GFP at an MOI of 0.1 and allowed to incubate for $24 \mathrm{~h}$ at $37^{\circ} \mathrm{C}$ with $5 \% \mathrm{CO}_{2}$ before supernatants were collected for TCID50 quantification as described above.

\subsection{Statistical analyses}

All data sets were tested for a normal distribution (Shapiro-Wilk) and homogeneity of variance (Levene's) using R and RStudio (R Core Team, 2014; RStudio Team, 2015). Further statistical analyses were also completed using R and RStudio. For the viability, VSV gene expression and viral titer data, a one-way analysis of variance (ANOVA) was completed followed by a Tukey's post-hoc test to compare between all exposure conditions. When determining whether the IFN genes were upregulated, a one-way ANOVA was completed followed by a Dunnett's multiple comparisons post-hoc test to detect significant differences from the control condition. With the siRNA transfection data, a two-tailed unpaired t-test was completed. For all statistical analyses, a p-value less than 0.05 was considered significant. All data is presented as the average of experimental replicates + SEM.

\section{Acknowledgements:}

The authors would like to acknowledge Dr. Tamiru Alkie for his help with establishing the primary bronchial epithelial/tracheal cell cultures.

\section{Author Contributions:}

RJ performed the experiments involving SARS-CoV-2 and the associated analyses. KM contributed to experimental design and funding of the SARS-CoV-2 work. SS performed the remaining experiments, all of the associated analyses, contributed to experimental design and wrote the first draft of the manuscript. SDO contributed to experimental design, funding of the project, and writing of the manuscript. All authors contributed to manuscript revisions and approved the final submitted version.

\section{Conflict of Interest:}

The authors declare that this research was conducted in the absence of any commercial or financial relationships that could be interpreted as a potential conflict of interest. 


\section{References:}

1. Alemán LM, Doench J, Sharp PA (2007) Comparison of siRNA-induced off-target RNA and protein effects. $R N A, 13: 385-395$

2. Alexopoulou L, Holt AC, Medzhitov R, Flavell RA (2001) Recognition of double-stranded RNA and activation of NF-kB by toll-like receptor 3. Nature, 413:732-738

3. Antonelli A, Ferrari SM, Fallahi P, Ghiri E, Crescioli C, Romagnani P, et al. (2010) Interferon-alpha, -beta and -gamma induce CXCL9 and CXCL10 secretion by human thyrocytes: modulation by peroxisome proliferator-activated receptor-gamma agonists. Cytokine, 50:260-267

4. Balakrishnan KN, Abdullah AA, Bala JA, Jesse FFA, Abdullah CAC, Noordin MM, et al. (2020) Multiple gene targeting siRNAs for down regulation of Immediate Early-2 (Ie2) and DNA polymerase genes mediated inhibition of novel rat Cytomegalovirus (strain All-03). Virology Journal, doi: 10.1186/s12985-020-01436-5

5. Banerjee A, Nasir JA, Budylowski P, Yip L, Aftanas P, Christie N, et al. (2020) Isolation, sequence, infectivity and replication kinetics of severe acute respiratory syndrome coronavirus 2. Emerging Infectious Disease, 26:2054-2063

6. Bernstein E, Caudy AA, Hammond SM, Hannon GJ (2001) Role for a bidentate ribonuclease in the initiation step of RNA interference. Nature, 409:363-366

7. Billy E, Brondani V, Zhang H, Müller U, Filipowicz W (2001) Specific interference with gene expression induced by long, double-stranded RNA in mouse embryonal teratocarcinoma cell lines. PNAS, 98:14428-14433

8. Bogerd HP, Skalsky RL, Kennedy EM, Furuse Y, Whisnant AW, Flores O, et al. (2014) Replication of many human viruses is refractory to inhibition by endogenous cellular microRNAs. Journal of Virology, doi: 10.1128/JVI.00985-14

9. Bolívar S, Anfossi R, Humeres C, Vivar R, Boza P, Muñoz C, et al. (2018) IFN- $\beta$ plays both pro- and anti-inflammatory roles in the rat cardiac fibroblast through differential STAT protein activation. Frontiers in Pharmacology, doi: 10.3389/fphar.2018.01368

10. Borden EC, Sen GC, Uze G, Silverman RH, Ransohoff RM, Foster GR, Stark GR (2007) Interferons at age 50: past, current and future impact on biomedicine. Nature Reviews Drug Discovery, 6:975-990

11. Buttmann M, Berberich-Siebelt F, Serfling E, Rieckmann P (2007) Interferon-beta is a potent inducer of interferon regulatory factor-1/2-dependent IP-10/CXCL10 expression in primary human endothelial cells. Journal of Vascular Research, 44:51-60

12. Cheon HJ, Borden EC, Stark GR (2014) Interferons and their stimulated genes in the tumor microenvironment. Seminars Oncology, 41:156-173.

13. Clemens JC, Worby CA, Simonson-Leff N, Muda M, Maehama T, Hemmings BA, et al. (2000) Use of double-stranded RNA interference in Drosophila cell lines to dissect signal transduction pathways. $P N A S$, 97:6499-6503.

14. Dalton KP, Rose JK (2001) Vesicular stomatitis virus glycoprotein containing the entire green fluorescent protein on its cytoplasmic domain is incorporated efficiently into virus particles. Virology, 279:414-421.

15. De Waele J, Marcq E, Van Audenaerde JRM, Van Loenhout J, Deben C, Zwaenepoel K, et al. (2018) Poly(I:C) primes primary human glioblastoma cells for an immune response invigorated by PD-L1 blockade. Oncoimmunology, doi: 10.1080/2162402X.2017.1407899

16. De Waele J, Verhezen T, Van der Heijden S, Berneman ZN, Peeters M, Lardon F, et al. (2021) A systematic review on poly(I:C) and poly-ICLC in glioblastoma: adjuvants coordinating the unlocking of immunotherapy. Journal of Experimental \& Clinical Cancer Research, doi: 10.1186/s13046-02102017-2

17. DeWitte-Orr SJ, Collins SE, Bauer CMT, Bowdish DM, Mossman KL (2010) An accessory to the 'trinity': SR-As are essential pathogen sensors of extracellular dsRNA, mediating entry and leading to subsequent type I IFN responses. PLoS Pathogens, doi: 10.1371/journal.ppat.1000829 
18. DeWitte-Orr SJ, Mehta DR, Collins SE, Suthar M, Gale MJ, Mossman KL (2009) Long dsRNA induces an antiviral response independent of IRF3, IPS-1 and IFN. The Journal of Immunology, doi: 10.4049/jimmunol.0900867

19. DeWitte-Orr SJ, Mossman KL (2010) DsRNA and the innate antiviral immune response. Future Virology, doi: https://doi.org/10.2217/fvl.10.18

20. Dick RS, Hubbell HR (1987) Sensitivities of human glioma cell lines to interferons and double-stranded RNAs individually and in synergistic combinations. Journal of Neuro-Oncology, 5:331-338

21. Elbashir SM, Harborth J, Lendeckel W, Yalcin A, Weber K, Tuschi T (2001) Duplexes of 21-nucleotide RNAs mediate RNA interference in cultured mammalian cells. Nature, 411:494-498

22. Everts B, Amiel E, Huang SC-C, Smith AM, Chang C-H, Lam WY, et al. (2014) TLR-driven early glycolytic reprogramming via the kinases TBK1-IKK $\varepsilon$ supports the anabolic demands of dendritic cell activation. Nature Immunology, 15:323-332

23. Feinberg EH, Hunter CP (2003) Transport of dsRNA into cells by the transmembrane protein SID-1. Science, 301:1545-1547

24. Fire A, Albertson D, Harrison SW, Moerman DG (1991) Production of antisense RNA leads to effective and specific gene expression in C. elegans muscle. Development, 113:503-514.

25. Fire A, Xu S, Montgomery MK, Kostas SA, Driver SE, Mello CC (1998) Potent and specific genetic interference by double-stranded RNA in Caenorhabditis elegans. Nature, 391:806-811.

26. Fritsch SD, Weichhart T (2016) Effects of interferons and viruses on metabolism. Frontiers in Immunology, doi: 10.3389/fimmu.2016.00630

27. Ge Q, McManus MT, Nguyen T, Shen C-H, Sharp PA, Eisen HN, et al. (2003) RNA interference of influenza virus production by directly targeting mRNA for degradation and indirectly inhibiting all viral RNA transcription. PNAS, 100:2718-2723

28. Geisbert TW, Lee ACH, Robbins M, Geisbert JB, Honko AN, Sood V, et al. (2010) Postexposure protection of non-human primates against a lethal Ebola virus challengs with RNA interference: a proof-of-concept study. The Lancet, 375:1896-1905

29. Gitlin L, Karelsky S, Andino R (2002) Short interfering RNA confers intracellular antiviral immunity in human cells. Nature, 418:430-434

30. Guo S, Kemphues KJ (1995) par-1, a gene required for establishing polarity in C. elegans embryos, encodes a putative Ser-Thr kinase that is asymmetrically distributed. Cell, 81:611-620.

31. Hägele H, Allam R, Pawar RD, Anders H-J (2009) Double-stranded RNA activates type I interferon secretion in glomerular endothelial cells via retinoic acid-inducible gene (RIG)-1. Nephrology Dialysis Transplantation, 24:3312-3318.

32. He W, Xu W, Xu L, Fu K, Guo W, Bock R, et al. (2020) Length-dependent accumulation of doublestranded RNAs in plastids affects RNA interference efficiency in the Colorado potato beetle. Journal of Experimental Botany, 71:2670-2677.

33. Hemmi H, Takeuchi O, Sato S, Yamamoto M, Kaisho T, Sanjo H, et al. (2004) The roles of two IkB kinase-related kinases in lipopolysaccharide and double stranded RNA signaling and viral infection. The Journal of Experimental Medicine, 199:1641-1650

34. Bautista-Hernández LA, Gómez-Olivares JL, Buentello-Volante B, Bautista-de Lucio VM (2017) Fibroblasts: the unknown sentinels eliciting immune responses against microorganisms. European Journal of Microbiology and Immunology, doi: 10.1556/1886.2017.00009

35. Imaizumi T, Numata A, Yano C, Yoshida H, Meng P, Hayakari R, et al. (2014) ISG54 and ISG56 are induced by TLR3 signaling in U373MG human astrocytoma cells: possible involvement in CXCL10 expression. Neuroscience Research, 84:34-42

36. Jensen S, Thomsen AR (2012) Sensing of RNA viruses: a review of innate immune receptors involved in recognizing RNA virus invasion. Journal of Virology, 86:2900-2910

37. Kato H, Takeuchi O, Mikamo-Satoh E, Hirai R, Kawai T, Matsushita K, et al. (2008) Length-dependent recognition of double-stranded ribonucleic acids by retinoic acid-inducible gene-I and melanoma differentiation-associated gene 5. The Journal of Experimental Medicine, 205:1601-1610 
38. Ketting RF, Fischer SEJ, Bernstein E, Sijen T, Hannon GJ, Plasterk RHA (2001) Dicer functions in RNA interference and in synthesis of small RNA involved in developmental timing in C. elegans. Genes \& Development, 15:2654-2659

39. Komal A, Noreen M, El-Kott AF (2021) TLR3 agonists: RGC100, ARNAX and poly-IC: a comparative review. Imunologic Research, 69:312-322.

40. Lee H-C, Chathuranga K, Lee J-S (2019) Intracellular sensing of viral genomes and viral evasion. Experimental \& Molecular Medicine, 51:1-13.

41. Leonard JN, Ghirlando R, Askins J, Bell JK, Margulies DH, Davies DR, et al. (2008) The TLR3 signaling complex forms by cooperative receptor dimerization. PNAS, 105:258-263

42. Li S, Gong M, Zhao F, Shao J, Xie Y, Zhang Y, Chang H (2018) Type I interferons: distinct biological activities and current applications for viral infection. Cellular Physiology and Biochemistry, 51:23772396.

43. Li W, Koutmou KS, Leahy DJ, Li M (2015) Systemic RNA interference deficiency-1 (SID-1) extracellular domain selectively binds long double-stranded RNA and is required for RNA transport by SID-1. RNA, 31:P18904-18913

44. Ma X, Kim E-J, Kook I, Ma F, Voshall A, Moriyama E, et al. (2013) Small interfering RNA-mediated translation alters ribosome sensitivity to inhibition by cycloheximide in Chlamydomonas reinhardtii ${ }^{[\mathrm{W}]}$. The Plant Cell, 25:985-998

45. Machitani M, Sakurai F, Wakabayashi K, Tomita K, Tachibana M, Mizuguchi H (2016) Dicer function as an antiviral system against human adenoviruses via cleavage of adenovirus-encoded noncoding RNA. Scientific Reports, doi: 10.1038/srep27598

46. Maillard PV, Ciaudo C, Marchais A, Li Y, Jay F, Ding SW, et al. (2013) Antiviral RNA interference in mammalian cells. Science, 342:235-238

47. Maillard PV, Van der Veen AG, Deddouche-Grass S, Rogers NC, Merits A, Reis e Sousa C (2016) Inactivation of the type I interferon pathway reveals long double-stranded RNA-mediated RNA interference in mammalian cells. The EMBO Journal, 35:2505-2518

48. Maillard PV, Van der Veen AG, Poirier EZ, Reis e Sousa C (2019) Slicing and dicing viruses: antiviral RNA interference in mammals. The EMBO Journal, doi: 10.15252/embj.2018100941

49. Matskevich AA, Moelling K (2007) Dicer is involved in protection against influenza A virus infection. Journal of General Virology, doi: 10.1099/vir.0.83103-0

50. Matsumoto M, Funami K, Tateatsu M, Azuma M, Seya T (2014) Assessment of the toll-like receptor 3 pathway in endosomal signaling. Methods in Enzymology, 535:149-165

51. Meshram CD, Singh NK, Sonwane AA, Pawar SS, Mishra BP, Chaturvedi VK, et al. (2013) Evaluation of single and dual siRNAs targeting rabies virus glycoprotein and nucleoprotein genes for inhibition of virus multiplication in vitro. Archives of Virology, doi: 10.1007/s00705-013-1738-z

52. Nellimarla S, Mossman KL (2014) Extracellular dsRNA: its function and mechanism of cellular uptake. Journal of Interferon and Cytokine Research, doi: 10.1089/jir.2014.0002

53. Nguyen TA, Smith BRC, Tate MD, Belz GT, Barrios MH, Elgass KD, et al. (2017) SIDT2 transports extracellular dsRNA into the cytoplasm for innate immune recognition. Immunity, 47:498-509

54. Paddison PJ, Caudy AA, Hannon GJ (2002) Stable suppression of gene expression by RNAi in mammalian cells. PNAS, 99:1443-1448

55. Parrish S, Fleenor J, Xu S, Mello C, Fire A (2000) Functional anatomy of a dsRNA trigger: differential requirement for the two trigger strands in RNA interference. Molecular Cell, 6:1077-1087

56. Poynter SJ, DeWitte-Orr SJ (2018) Understanding viral dsRNA-mediated innate immune responses at the cellular level using a rainbow trout model. Frontiers Immunology, doi: 10.3389/fimmu.2018.00829

57. Qui Y, Xu Y-P, Wang M, Miao M, Zhou H, Xu J, et al. (2020) Flavivirus induces and antagonizes antiviral RNA interference in both mammals and mosquitoes. Science Advances, doi: 10.1126/sciadv.aax7989

58. Reed LJ, Muensch H (1938) A simple method of estimating fifty per cent endpoints. American Journal of Epidemiology, 27:493-497. 
59. Rehwinkel J, Gack GU (2020) RIG-I-like receptors: their regulation and roles in RNA sensing. Nature Reviews Immunology, 20:537-551

60. Rich A, Davies DR (1956) A new two-stranded helical structure: polyadenylic acid and polyuridylic acid. The Journal of the American Chemical Society, 78:3548.

61. Sakurai K, Amarzguioui M, Kim D-H, Alluin J, Heale B, Song M-S, et al. (2011) A role for human Dicer in pre-RISC loading of siRNAs. Nucleic Acids Research, 39:1510-1525

62. Saleh M-C, van Rij RP, Hekele A, Gillis A, Foley E, O'Farrell PH, et al. (2006) The endocytic pathway mediates cell entry of dsRNA to induce RNAi silencing. Nature Cell Biology, doi: 10.1038/ncb1439

63. Scadden ADJ (2007) Inosine-containing dsRNA binds a stress-granule-like complex and downreguates gene expression in trans. Molecular Cell, 28:491-500

64. Schuster S, Miesen P, van Rij RP (2019) Antiviral RNAi in insects and mammals: parallels and differences. Viruses, doi: 10.3390/v11050448

65. Seo GJ, Kincaid RP, Phanaksri T, Burke JM, Pare JM, Cox JE, et al. (2013) Reciprocal inhibition between intracellular antiviral signaling and the RNAi machinery in mammalian cells. Cell Host and Microbe, 14:435-445

66. Singh NK, Meshram CD, Sonwane AA, Dahiya SS, Pawar SS, Chaturvedi VK, et al. (2014) Protection of mice against lethal rabies virus challenge using short interfering RNAs (siRNAs) delivered through lentiviral vector. Molecular Biotechnology, doi: 10.1007/s12033-013-9685-1

67. Son KN, Liang Z, Lipton HL (2015) Double-stranded RNA is detected by immunofluorescence analysis in RNA and DNA virus infections, including those by negative-stranded RNA viruses. Journal of Virology, 89:9383-9392

68. Tatematsu M, Funami K, Seya T, Matsumoto M (2018) Extracellular RNA sensing by pattern recognition receptors. Journal of Innate Immunity, 10:398-406

69. Ulvila J, Parikka M, Kleino A, Sormunen R, Ezekowitze RA, Kocks C, Rämet M (2006) Doublestranded RNA is internalized by scavenger receptor-mediated endocytosis in Drosophila S2 cells. Genomics, Proteomics, and Bioinformatics, 281:P14370-14375

70. Van den Berg A, Mols J, Han J (2008) RISC-target interaction: cleavage and translational suppression. Biochimica et Biophysica Acta, 1779:668-677.

71. Van der Veen AG, Maillard PV, Schmidt JM, Lee SA, Deddouche-Grass S, Borg A, et al. (2018) The RIG-I-like receptor LGP2 inhibits Dicer-dependent processing of long double-stranded RNA and blocks RNA interference in mammalian cells. The EMBO Journal, doi: 10.15252/embj.201797479

72. Wang Y, Kato N, Jazag A, Dharel N, Otsuka M, Taniguchi H, et al. (2006) Hepatitis C virus core protein is a potent inhibitor of RNA silencing-based antiviral response. Gastroenterology, 130:883-892

73. Watson, J.D., and Crick, F.H.C. (1953) Molecular Structure of Nucleic Acids: A Structure for Deoxyribose Nucleic Acid. Nature, doi: 10.1038/171737a0

74. Weber F, Wagner V, Rasmussen SB, Hartmann R, Paludan SR (2006) Double-stranded RNA is produced by positive-strand RNA viruses and DNA viruses but not in detectable amounts by negativesense RNA viruses. Journal of Virology, 80:5059-5064.

75. Wheeler LA, Vrbanac V, Trifonova R, Brehm MA, Gilboa-Geffen A, Tanno S, et al. (2013) Durable knockdown and protection from HIV transmission in humanized mice treated with gel-formulated CD4 aptamer-siRNA chimeras. Molecular Therapy, 21:1378-1389

76. Winston WM, Molodowitch C, Hunter CP (2002) Systemic RNAi in C. elegans requires the putative transmembrane protein SID-1. Science, 295:2456-2459

77. Wollmann G, Robek MD, Van den Pol AN (2007) Variable deficiencies in the interferon response enhance susceptibility to vesicular stomatitis virus oncolytic actions in glioblastoma cells but not in normal human glial cells. Journal of Virology, 81:1479-1491

78. Wu R, Luo KQ (2021) Developing effective siRNAs to reduce the expression of key viral genes of COVID-19. International Journal of Biological Sciences, 17:1521-1529

79. Yang E, Li MMH (2020) All about the RNA: interferon-stimulated genes that interfere with viral RNA processes. Frontiers in Immunology, doi: 10.3389/fimmu.2020.605024 
860

861

862

863

864

865

866

867

868

869

870

871

872

873

874

875

876

877

878

879

880

881

882

883

884

885

886

887

888

889

3

886

80. Yang L, Lu J, Han Y, Fan X, Ding S-W (2013) RNA interference functions as an antiviral immunity mechanism in mammals. Science, 342:231-234

81. Yang S, Tutton S, Pierce E, Yoon K (2001) Specific double-stranded RNA interference in undifferentiated mouse embryonic stem cells. Molecular and Cellular Biology, 21:7807-7816

82. Zhang H, Kolb FA, Brondani V, Billy E, Filipowicz W (2002) Human Dicer preferentially cleaves dsRNAs at their termini without a requirement for ATP. The EMBO Journal, 21:5875-5885

.

(1)

0

1

2

4

75

6

877

8

81

82

8


890 Table 1: Primers with underlined T7 promoter sequences that were used for amplification of genes of 891 interest for dsRNAi. The resulting DNA amplicons were then used for dsRNA synthesis. The resultant 892 dsRNA length and the original template DNA used for each primer set is also outlined.

\begin{tabular}{|c|c|c|c|}
\hline Primer & $\begin{array}{l}\text { dsRNA } \\
\text { Length }\end{array}$ & Sequence $\left(5^{\prime}-3^{\prime}\right)$ & Template \\
\hline \multirow{6}{*}{ GFP } & 700 bp & $\begin{array}{l}\text { F: TAATACGACTCACTATAGGGAGAGTGAGCAAGGGCGAGGAGCTG } \\
\text { R: TAATACGACTCACTATAGGGAGATTACTTGTACAGCTCGTCCATGC }\end{array}$ & \multirow{6}{*}{$\begin{array}{l}\text { peGFP-C1 } \\
\text { plasmid }\end{array}$} \\
\hline & $600 \mathrm{bp}$ & $\begin{array}{l}\text { F: TAATACGACTCACTATAGGGAGAGTGAGCAAGGGCGAGGAGCTG } \\
\text { R: TAATACGACTCACTATAGGGAGAGGTAGTGGTTGTCGGGCAGCAG }\end{array}$ & \\
\hline & $500 \mathrm{bp}$ & $\begin{array}{l}\text { F: TAATACGACTCACTATAGGGAGAGTGAGCAAGGGCGAGGAGCTG } \\
\text { R: TAATACGACTCACTATAGGGAGAATCTTGAAGTTCACCTTGATGCCG }\end{array}$ & \\
\hline & 400 bp & $\begin{array}{l}\text { F: TAATACGACTCACTATAGGGAGAGTGAGCAAGGGCGAGGAGCTG } \\
\text { R: TAATACGACTCACTATAGGGAGAATCTTGAAGTTCACCTTGATG }\end{array}$ & \\
\hline & 300 bp & $\begin{array}{l}\text { F: TAATACGACTCACTATAGGGAGAGTGAGCAAGGGCGAGGAGCTG } \\
\text { R: TAATACGACTCACTATAGGGAGAGAAGAAGATGGTGCGCTCCTG }\end{array}$ & \\
\hline & 200 bp & $\begin{array}{l}\text { F: TAATACGACTCACTATAGGGAGAGTGAGCAAGGGCGAGGAGCTG } \\
\text { R: TAATACGACTCACTATAGGGAGACCGTAGGTCAGGGTGGTCACG }\end{array}$ & \\
\hline mCherry & 700 bp & $\begin{array}{l}\text { F: TAATACGACTCACTATAGGGAGAGATAACATGGCCATCATCAAGG } \\
\text { R: TAATACGACTCACTATAGGGAGACCGGTGGAGTGGCGGCCC }\end{array}$ & $\begin{array}{l}\text { pemCherry- } \\
\text { C1 plasmid }\end{array}$ \\
\hline$\beta$-lac & 750 bp & $\begin{array}{l}\text { F: TAATACGACTCACTATAGGGAGATGGGTGCACGAGTGGGTTACATCG } \\
\text { R: TAATACGACTCACTATAGGGAGAGTTACCAATGCTTAATCAGTGAGGC }\end{array}$ & $\begin{array}{l}\text { pFastBacHTA } \\
\text { plasmid }\end{array}$ \\
\hline $\begin{array}{l}\text { VSV M } \\
\text { Protein }\end{array}$ & 700 bp & $\begin{array}{l}\text { F: TAATACGACTCACTATAGGGAGAGATTCTCGGTCTGAAGGGGAAAGG } \\
\text { R: TAATACGACTCACTATAGGGAGAGAATTGTTCAGAAGCTGGAAGCTAGAC }\end{array}$ & \multirow{2}{*}{$\begin{array}{l}\text { cDNA from } \\
\text { VSV infected } \\
\text { cells }\end{array}$} \\
\hline $\begin{array}{l}\text { VSV N } \\
\text { Protein }\end{array}$ & 700 bp & $\begin{array}{l}\text { F: TAATACGACTCACTATAGGGAGATCTGTTACAGTCAAGAGAATCATTG } \\
\text { R: TAATACGACTCACTATAGGGAGATTGCAGAGGTGTCCAAATCT }\end{array}$ & \\
\hline $\begin{array}{c}229 \mathrm{E} \mathrm{M} \\
\text { Protein }\end{array}$ & 700 bp & $\begin{array}{l}\text { F: TAATACGACTCACTATAGGGAGACCAATCATATATGCACATAGACC } \\
\text { R: TAATACGACTCACTATAGGGAGAGTCATGTTGCTCATGGGAG }\end{array}$ & \multirow{4}{*}{$\begin{array}{l}\text { cDNA from } \\
\text { HCoV-229E } \\
\text { infected cells }\end{array}$} \\
\hline $\begin{array}{l}229 \mathrm{E} \mathrm{N} \\
\text { Protein }\end{array}$ & $700 \mathrm{bp}$ & $\begin{array}{l}\text { F: TAATACGACTCACTATAGGGAGAGTTGCTGTTGATGGTGCTAA } \\
\text { R: TAATACGACTCACTATAGGGAGATACCCAAGTGTGGATGGTCT }\end{array}$ & \\
\hline $\begin{array}{l}\text { 229E Spike } \\
\text { Protein }\end{array}$ & 700 bp & $\begin{array}{l}\text { F: TAATACGACTCACTATAGGGAGAACCTAGCTTGCCCAGAAGTG } \\
\text { R: TAATACGACTCACTATAGGGAGAAAGCTGTCTGGAAGCACGAA }\end{array}$ & \\
\hline $\begin{array}{l}\text { 229E RdRp } \\
\text { Protein }\end{array}$ & 700 bp & $\begin{array}{l}\text { F: TAATACGACTCACTATAGGGAGATTATAGTTGCGTCATCGCCT } \\
\text { R: TAATACGACTCACTATAGGGAGATTAGGATCGTCAACATCGGC }\end{array}$ & \\
\hline $\begin{array}{l}\text { SARS-CoV-2 } \\
\text { N Protein }\end{array}$ & 700 bp & $\begin{array}{l}\text { F: TAATACGACTCACTATAGGGAGATACTGCGTCTTGGTTCACC } \\
\text { R: TAATACGACTCACTATAGGGAGAATTTCTTAGTGACAGTTTGGCCT }\end{array}$ & $\begin{array}{l}\text { IDT CoV N } \\
\text { plasmid }\end{array}$ \\
\hline $\begin{array}{l}\text { SARS-CoV-2 } \\
\text { M Protein }\end{array}$ & $700 \mathrm{bp}$ & $\begin{array}{l}\text { F: TAATACGACTCACTATAGGGAGATGGCAGATTCCAACGGTA } \\
\text { R: TAATACGACTCACTATAGGGAGAGCCAATCCTGTAGCGACTG }\end{array}$ & $\begin{array}{l}\text { SARS-CoV-2 } \\
\text { M gBlock }\end{array}$ \\
\hline M-3' & 700 bp & $\begin{array}{l}\text { F: TAATACGACTCACTATAGGGAGATCTGTTACAGTCAAGAGAATCATTG } \\
\text { R: TAATACGACTCACTATAGGGAGAGAATTGTTCAGAAGCTGGAAGCTAGAC }\end{array}$ & $\begin{array}{l}\text { 5'N-M-3' } \\
\text { gBlock }\end{array}$ \\
\hline N-M Alt. & 700 bp & $\begin{array}{l}\text { F: TAATACGACTCACTATAGGGAGATCTGTTACAGTCAAGAGAATCATTG } \\
\text { R: TAATACGACTCACTATAGGGAGACTGGAGTGGCCTTTAGATTAGAAG }\end{array}$ & $\begin{array}{l}\text { N-M Alt } \\
\text { gBlock }\end{array}$ \\
\hline
\end{tabular}


Table 2: Primers used for qRT-PCR analyses and for SARS-CoV-2 qPCR quantification.

905

\begin{tabular}{|c|c|c|c|}
\hline Primer & Sequence (5'-3') & $\begin{array}{l}\text { Genbank No. or } \\
\text { Reference }\end{array}$ & Application \\
\hline$\beta$-Actin & $\begin{array}{l}\text { F: CTGGCACCCAGCACAATG } \\
\text { R: CCGATCCACACGGAGTACTTG }\end{array}$ & NM_001101.5 & \multirow{5}{*}{ qRT-PCR } \\
\hline IFN $\beta$ & $\begin{array}{l}\text { F: AAACTCATGAGCAGTCTGCA } \\
\text { R: AGGAGATCTTCAGTTTCGGAGG }\end{array}$ & NM_002176.4 & \\
\hline CXCL10 & $\begin{array}{l}\text { F: GAAAGCAGTTAGCAAGGAAAGG } \\
\text { R: GACATATACTCCATGTAGGGAAGTG }\end{array}$ & XM_003832298.2 & \\
\hline VSV N Protein & $\begin{array}{l}\text { F: CGACCTGGATCTTGAACC } \\
\text { R: AGGCAGGGTTTTTGACG }\end{array}$ & X04452.1 & \\
\hline VSV M Protein & $\begin{array}{l}\text { F: GTACATCGGAATGGCAGG } \\
\text { R: TGAGCGTGATACTCGGG }\end{array}$ & M15213.1 & \\
\hline SARS-CoV-2 & $\begin{array}{l}\text { F: ATTGTTGATGAGCCTGAAG } \\
\text { R: TTCGTACTCATCAGCTTG }\end{array}$ & Banerjee et al., 2020 & $\begin{array}{l}\text { SARS-CoV-2 } \\
\text { Quantification }\end{array}$ \\
\hline
\end{tabular}

906

907

908

909

910

911

912

913

914

915

916

917

918

919

920

921

922

923

924

925 
Figure 1: Type I IFN gene expression is not stimulated by soaking cells with low doses of dsRNA. Both THF (A) and SNB75 (B) cells were soaked with $700 \mathrm{bp}$ dsRNA for $26 \mathrm{~h}$ at concentrations of $0.5 \mu \mathrm{g} / \mathrm{mL}$ and $10 \mu \mathrm{g} / \mathrm{mL}$ as well as with HMW pIC at a concentration of $10 \mu \mathrm{g} / \mathrm{mL}$. Following treatment, transcript expression of $I F N \beta$ (i) and $C X C L 10$ (ii) was assessed via qRT-PCR analysis. All data were normalized to the reference gene $(\beta$-Actin) and expressed as a fold change over the control group where control expression was set to 1 . Error bars represent + SEM, and represents the average of 3 independent replicates. A p-value of less than 0.001 is represented by a *** symbol while a p-value of less than 0.0001 is represented by a **** symbol when compared only to the control $(\mathrm{Ctl})$ treatment.

935

936

937

938

939

940

941

942

943

944

945

946

947

948

949

950

951

952

953

954

955

956

957

958

959

960

961

962

963

964

965

966

967

968

969

Figure 2: Soaking cells with long dsRNA does not negatively influence cell viability. THF (i), SNB75 (ii) and MRC5 (iii) were soaked with $700 \mathrm{bp}$ dsRNA for $26 \mathrm{~h}$ at concentrations that ranged from $0 \mathrm{ng} / \mathrm{mL}$ to $800 \mathrm{ng} / \mathrm{mL}$. Cellular metabolism was measured using an Alamar Blue assay (A) and membrane integrity was measured using CFDA (B). Error bars represent + SEM, and each data point represents the average of 3 independent experiments. A p-value of less than 0.05 was considered to be statistically significant. Error bars with different letters represent significantly different data.

Figure 3: Viral knockdown is observed when pre-soaking cells with sequence-specific long dsRNA and this response is length dependent. THF (A) and SNB75 (B) cells were pre-soaked with either sequence specific (GFP) dsRNA ranging from $200 \mathrm{bp}$ to $700 \mathrm{bp}$ in length, non-sequence specific (mCherry or betalac) dsRNA of $700 \mathrm{bp}$ or DPBS as a control for $2 \mathrm{~h}$ prior to $24 \mathrm{~h}$ infection with VSV-GFP (MOI $=0.1$ ). Appearance of the THF cells after treatments with dsRNA and VSV-GFP infection as observed under the fluorescent microscope at $50 \mathrm{X}$ magnification $(\mathbf{C})$. Error bars represent $+\mathrm{SEM}$, and each data point represents the average of 6 independent replicates. A p-value of less than 0.05 was considered to be statistically significant. Error bars with different letters represent significantly different data.

Figure 4: Soaking cells with long dsRNA of viral genes can induce knockdown of the complementary virus. Both THF (A) and SNB75 (B) cells were pre-soaked for $2 \mathrm{~h}$ with either DPBS alone, $500 \mathrm{ng} / \mathrm{mL}$ of the mismatched dsRNA controls (mCherry or Beta-lac), $500 \mathrm{ng} / \mathrm{mL}$ of VSV N protein dsRNA, $500 \mathrm{ng} / \mathrm{mL}$ of VSV M protein dsRNA or a mixture of $250 \mathrm{ng} / \mathrm{mL} \mathrm{N}$ protein dsRNA with $250 \mathrm{ng} / \mathrm{mL}$ of M protein dsRNA before infection with VSV-GFP $(\mathrm{MOI}=0.1)$ for $24 \mathrm{~h}$. MRC5 cells were pre-soaked for $2 \mathrm{~h}$ with either DPBS alone, $500 \mathrm{ng} / \mathrm{mL}$ of the mCherry mis-matched dsRNA sequence control or $500 \mathrm{ng} / \mathrm{mL}$ of dsRNA matching $\mathrm{HCoV}-229 \mathrm{E}$ sequences for either RdRp, M protein, $\mathrm{N}$ protein and the spike protein before $24 \mathrm{~h}$ infection with $\mathrm{HCoV}-229 \mathrm{E}(\mathrm{MOI}=0.02)(\mathbf{C})$. Calu-3 cells were pre-soaked for $2 \mathrm{~h}$ with either DPBS alone, 1000 $\mathrm{ng} / \mathrm{mL}$ of the mCherry mis-matched dsRNA sequence control or $1000 \mathrm{ng} / \mathrm{mL}$ of dsRNA matching SARS$\mathrm{CoV}-2$ sequences for either $\mathrm{M}$ protein and $\mathrm{N}$ protein prior to $24 \mathrm{~h}$ infection with SARS-CoV-2 (MOI = 1.0) (D). Error bars represent + SEM, and each data point represents the average of 6 independent replicates. A p-value of less than 0.05 was considered to be statistically significant and different letters represent significant differences. For the SARS-CoV-2 data, a p-value of less than 0.01 is represented by a ** symbol and a p-value of less than 0.05 is represented by a * symbol when compared only to the control treatment

Figure 5: Primary Bronchial Epithelial/Tracheal Cells (pBECs) pre-soaked with long dsRNA of viral genes inhibits infection with corresponding viruses. The pBECs were grown to confluence and were shown to exhibit characteristics indicative of epithelial/tracheal cells, including mucous production and cilia function (A). The pBECs were pre-soaked with either DPBS, $500 \mathrm{ng} / \mathrm{mL}$ of the mis-matched mCherry dsRNA control or $500 \mathrm{ng} / \mathrm{mL}$ of VSV N protein dsRNA before infection with VSV-GFP (MOI = 0.1) for 24h (B). The pBECs were also pre-treated with either DPBS, $50 \mu \mathrm{g} / \mathrm{mL}$ of HMW pIC, $500 \mathrm{ng} / \mathrm{mL}$ of the mis-matched mCherry dsRNA control or $500 \mathrm{ng} / \mathrm{mL}$ of $\mathrm{HCoV}-229 \mathrm{E}$ M protein dsRNA before infection with $\mathrm{HCoV}$ - 
229E $(\mathrm{MOI}=0.1)$ for $24 \mathrm{~h}(\mathbf{C})$. Error bars represent + SEM, and each data point represents the average of 3 independent replicates. A p-value of less than 0.05 was considered to be statistically significant. Error bars with different letters represent significantly different data.

Figure 6: Soaking is sufficient for long dsRNA-induced antviral effects but not siRNA. THF (Ai) and SNB75 (Bi) were pre-soaked for $2 \mathrm{~h}$ with either DPBS, $2 \mathrm{nM}$ of long mCherry dsRNA, $2 \mathrm{nM}$ of long GFP dsRNA or $2 \mathrm{nM}$ of GFP siRNA prior to infection with VSV-GFP $(\mathrm{MOI}=0.1)$ for $24 \mathrm{~h}$. To ensure that the siRNA was functional, THF (Aii) and SNB75 (Bii) cells were transfected with either $10 \mathrm{nM}$ of GFP siRNA or $10 \mathrm{nM}$ of the negative control siRNA for $24 \mathrm{~h}$ prior to infection with VSV-GFP $(\mathrm{MOI}=0.1)$ for $24 \mathrm{~h}$. Error bars represent $+\mathrm{SEM}$, and each data point represents the average of 5 independent replicates. A pvalue of less than 0.05 was considered to be statistically significant and different letters represent significant differences. For the transfection data, a p-value of less than 0.01 is represented by a ${ }^{* *}$ symbol while less than 0.001 is represented by a $* * *$ symbol.

Figure 7: Combination dsRNA molecules can inhibit viruses through the knockdown of multiple viral genes. Three different 700 bp combination genes were synthesized using gBlocks referred to as 5' $\mathrm{N}-3$ ' $\mathrm{M}$, 5'M-3'N and N-M Alt (A). THF cells were pre-soaked for $2 \mathrm{~h}$ with DPBS or $500 \mathrm{ng} / \mathrm{mL}$ of either mCherry, 5'N-3'M, 5'M-3'N or N-M Alt before being exposed to VSV-GFP (MOI = 0.1) for 24h (Bi). Following this treatment, cells were collected and RNA extracted so that gene expression of the VSV N protein gene (Bii) and M protein gene (Biii) could be measured by qRT-PCR. THF cells were also pre-soaked for $2 \mathrm{~h}$ with DPBS or $1000 \mathrm{ng} / \mathrm{mL}$ of either mCherry, 5'N-3'M, 5'M-3'N or N-M Alt before being exposed to VSV-GFP $(\mathrm{MOI}=0.1)$ for $24 \mathrm{~h}(\mathbf{C i})$. Following this treatment, cells were collected and RNA extracted so that gene expression of the VSV N protein gene (Cii) and M protein gene (Ciii) could be measured by qRTPCR. Error bars represent +SEM. Each data point for the titer data represents the average of 6 independent replicates while the qRT-PCR data represents the average of 5 independent replicates. A p-value of less than 0.05 was considered to be statistically significant. Error bars with different letters represent significantly different data.

Figure 8: The observed viral inhibition by long dsRNA soaking is dependent on the presence of functional Dicer proteins. Mouse MSCs that had functional Dicer1 were pre-soaked for $2 \mathrm{~h}$ with DPBS or $500 \mathrm{ng} / \mathrm{mL}$ of either mis-matched mCherry dsRNA or matched GFP dsRNA before infection with VSV-GFP (MOI = 0.1 ) for $24 \mathrm{~h}$ (A). The matching mouse MSC cell line that was a KO for Dicer1 were also pre-soaked for $2 \mathrm{~h}$ with DPBS or $500 \mathrm{ng} / \mathrm{mL}$ of either mis-matched mCherry dsRNA or matched GFP dsRNA before infection with VSV-GFP $(\mathrm{MOI}=0.1)$ for $24 \mathrm{~h}(\mathbf{B})$. Error bars represent $+\mathrm{SEM}$, and each data point represents the average of 6 independent replicates. A p-value of less than 0.05 was considered to be statistically significant. Error bars with different letters represent significantly different data. 
A. THF

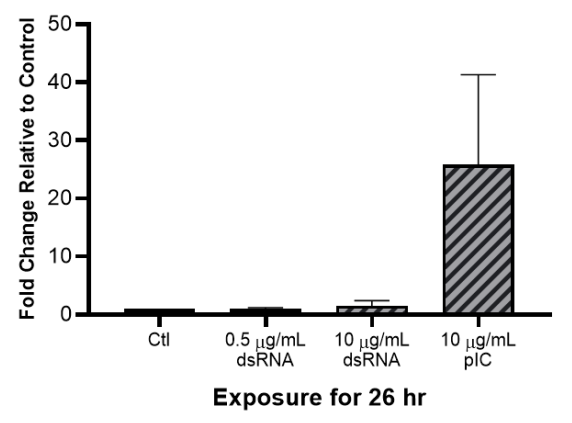

ii. CXCL10

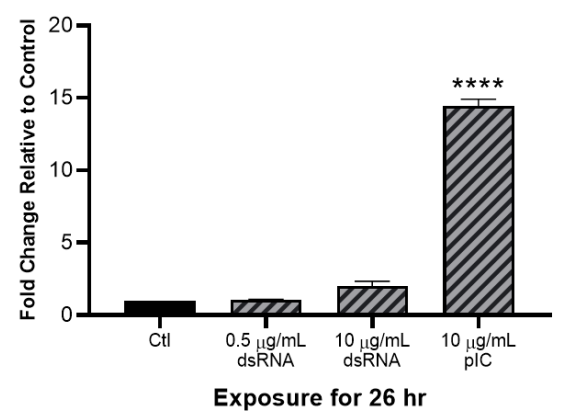

B. SNB75
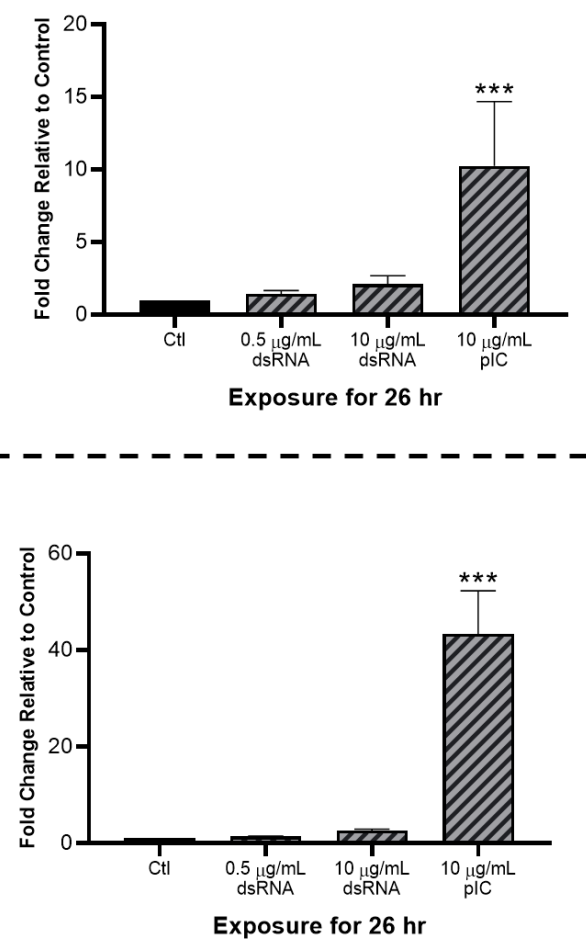


\section{A. Alamar Blue}

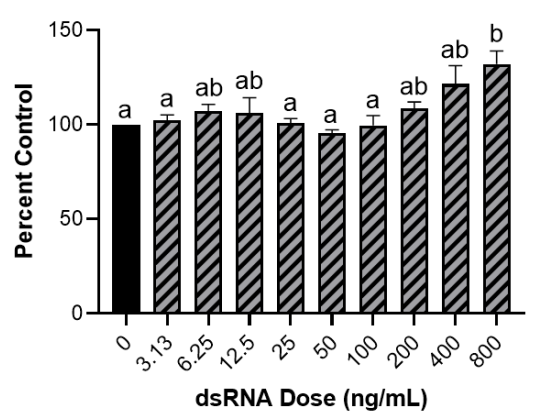

ii. SNB75

i. THF

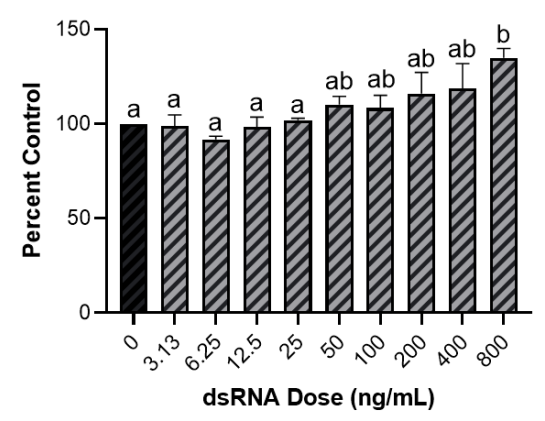

iii. MRC5

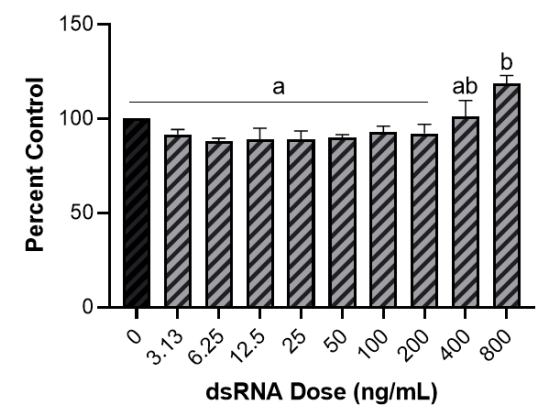

B. CFDA

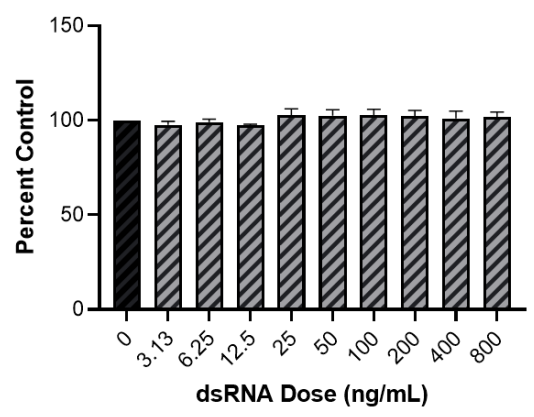

Figure 2

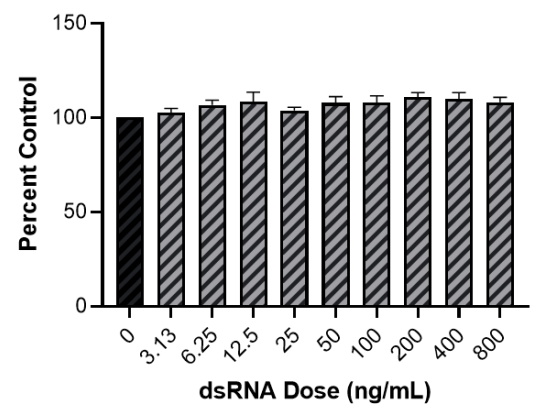




\section{A. THF}

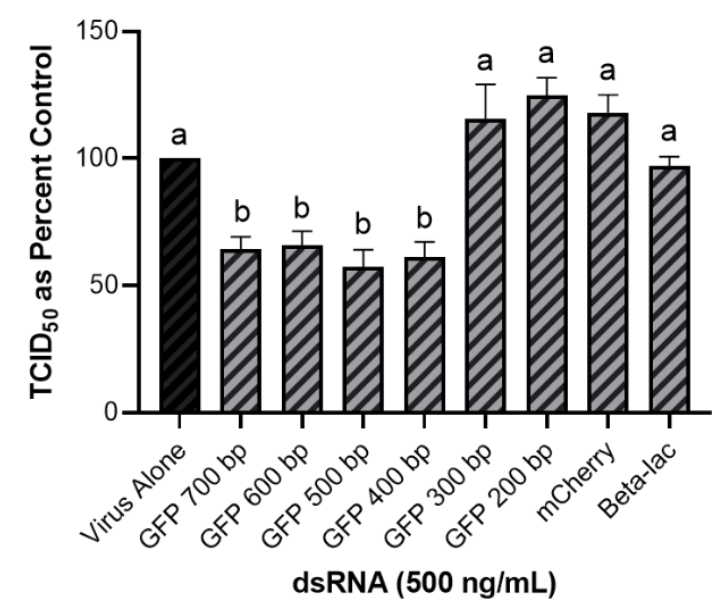

\section{B. SNB75}

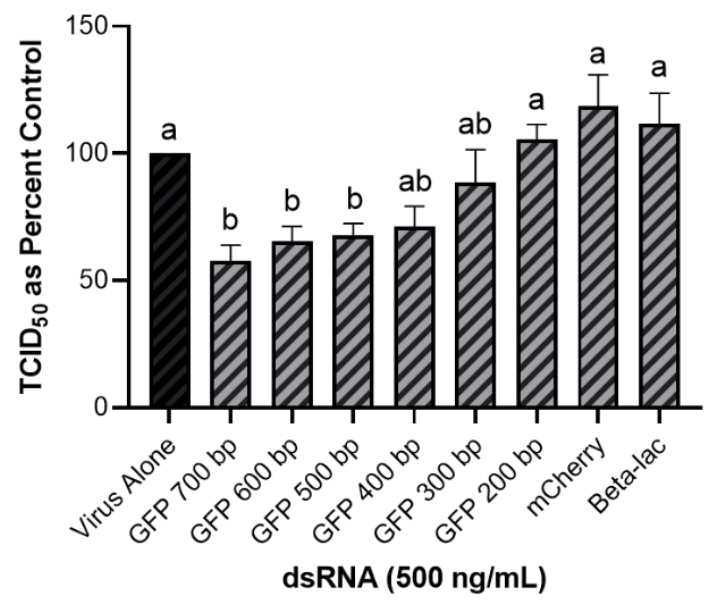

\section{Representative Images (THF)}
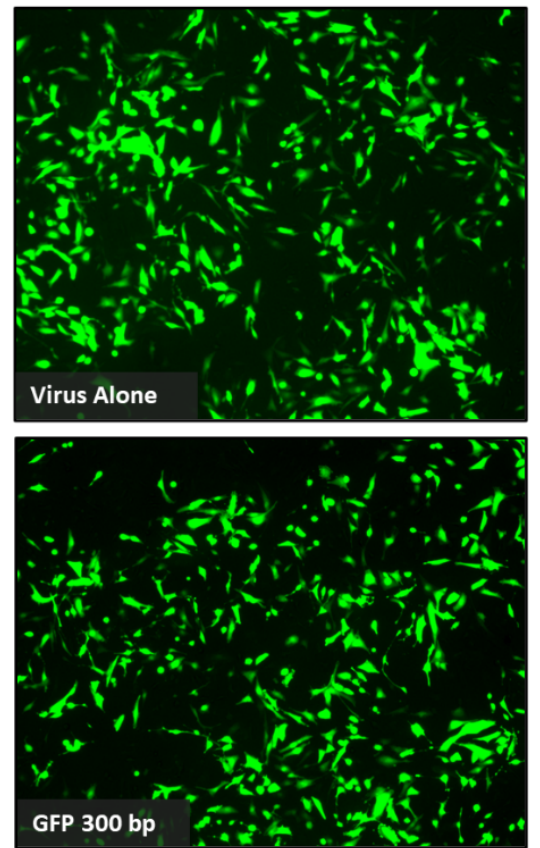
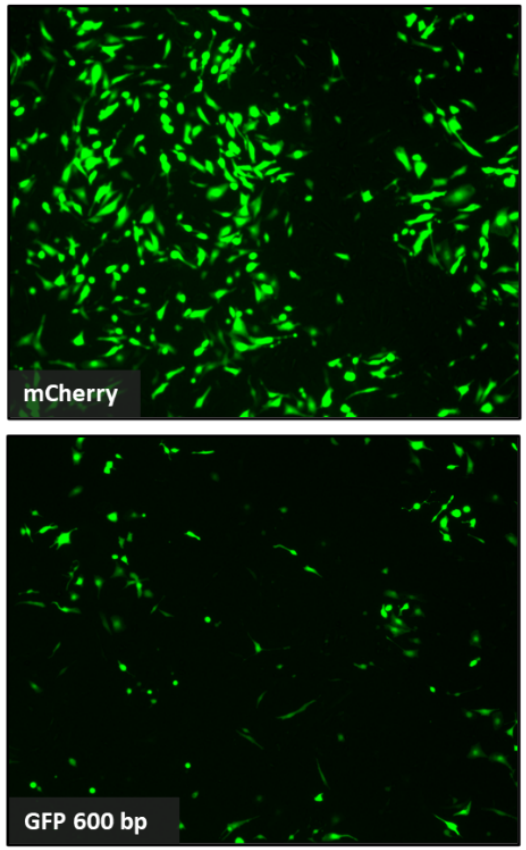
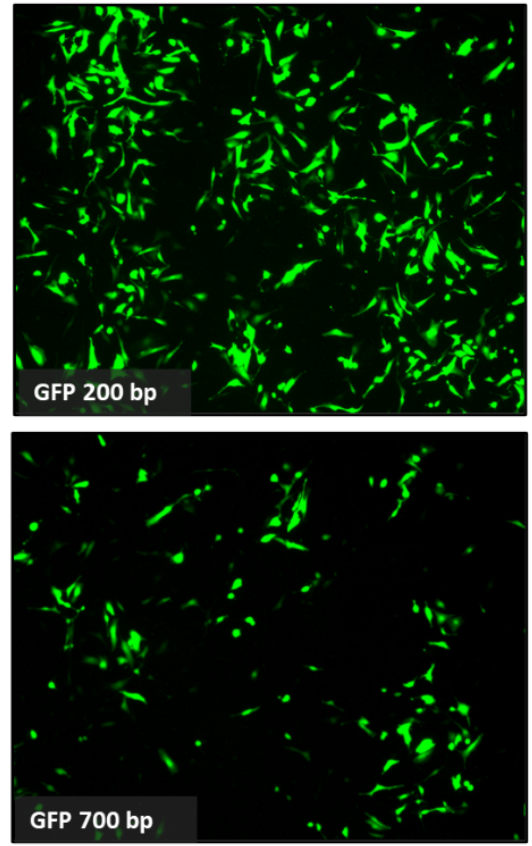

Figure 3 


\section{A. THF and VSV-GFP}

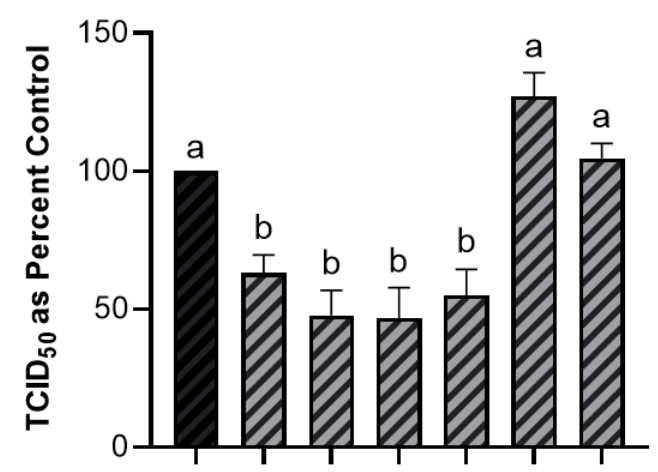

C. MRC5 and HCoV-229E

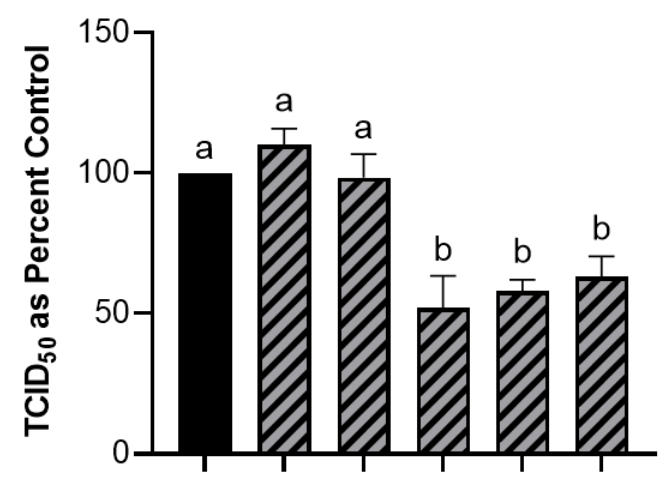

1036

1037

Figure 4

\section{B. SNB75 and VSV-GFP}

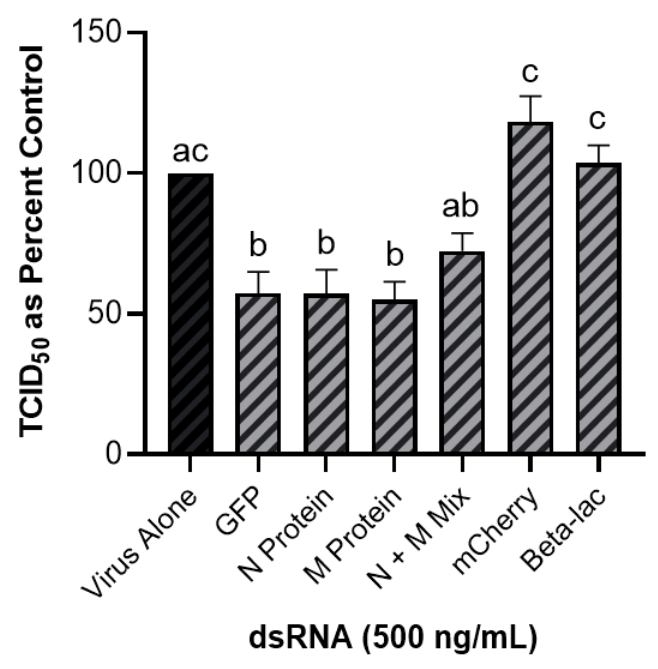

D. Calu-3 and SARS-CoV-2

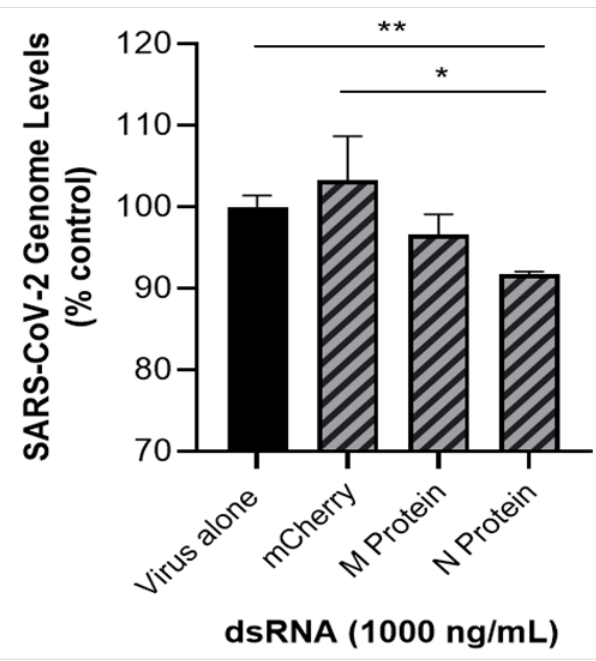

1038

1039 


\section{A. pBEC Morphology}

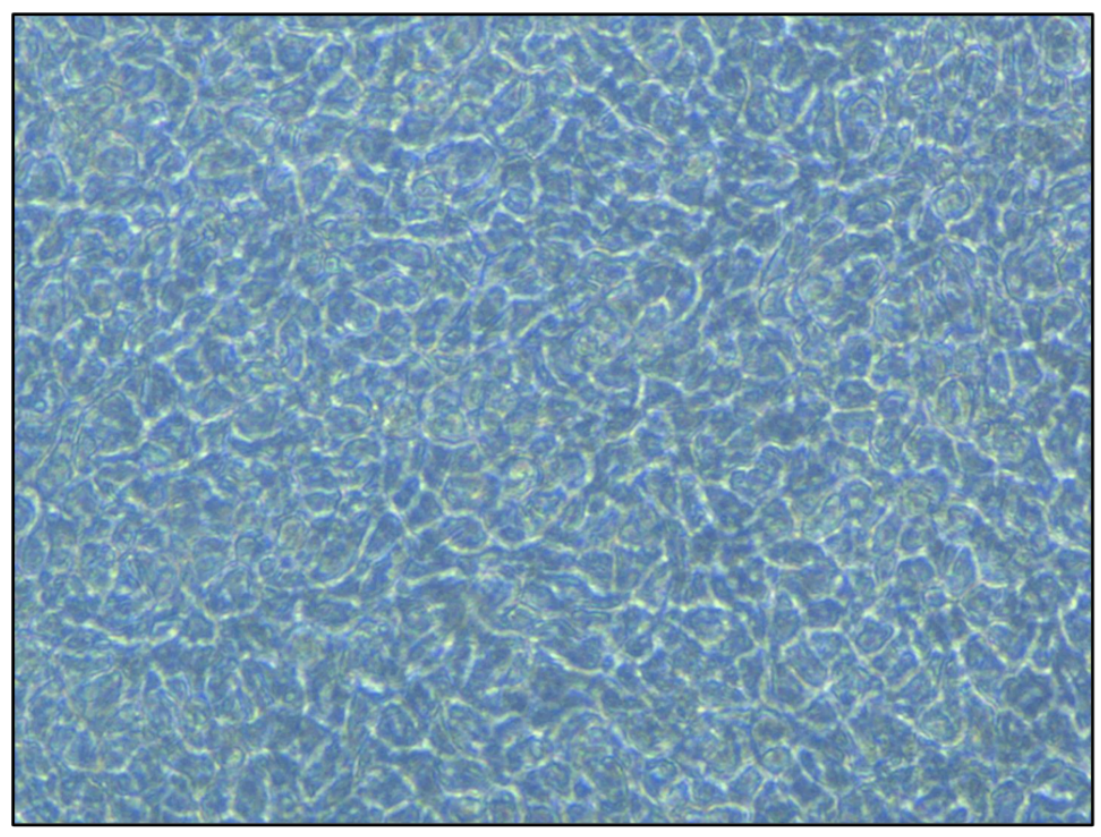

\section{B. pBECs and VSV-GFP}

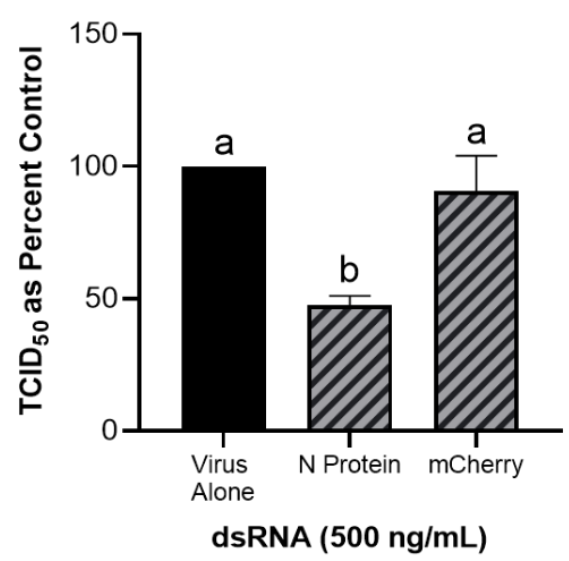

C. pBECs and HCoV-229E

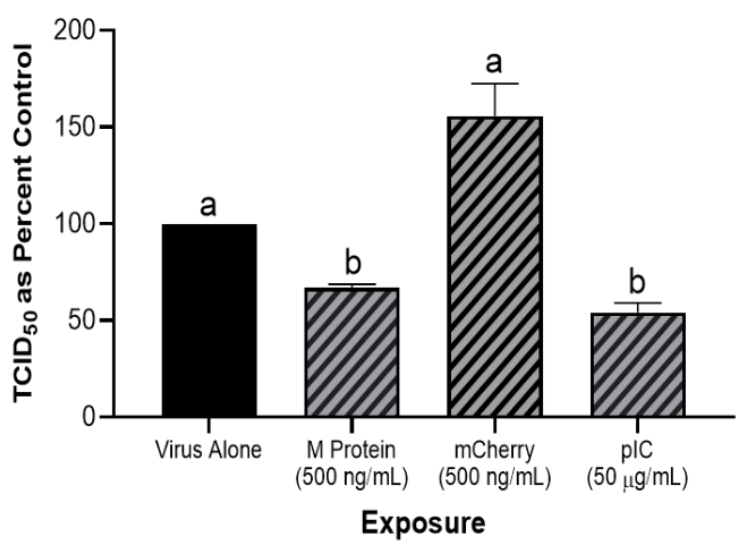

Figure 5 


\section{A. THF}

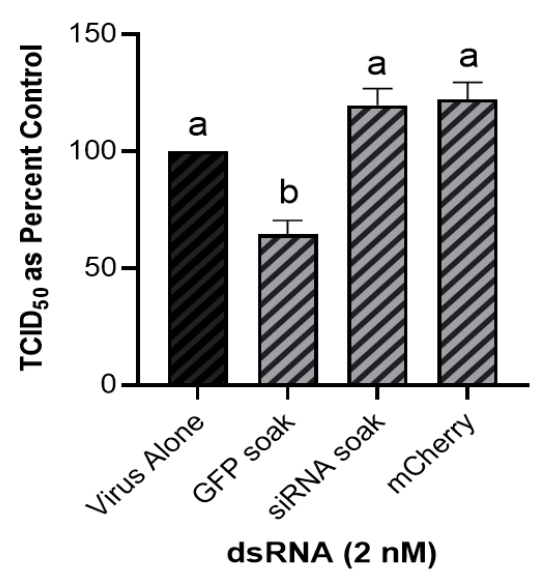

B. SNB75

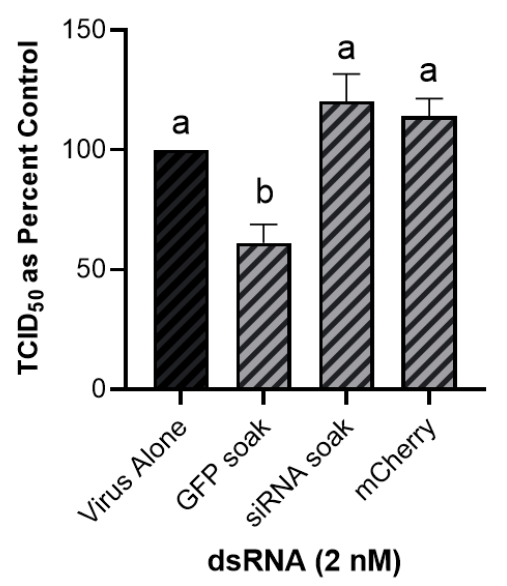

\section{ii. Transfection}

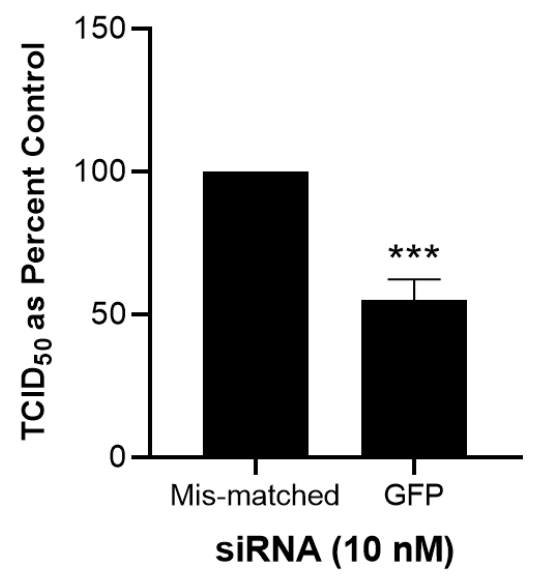

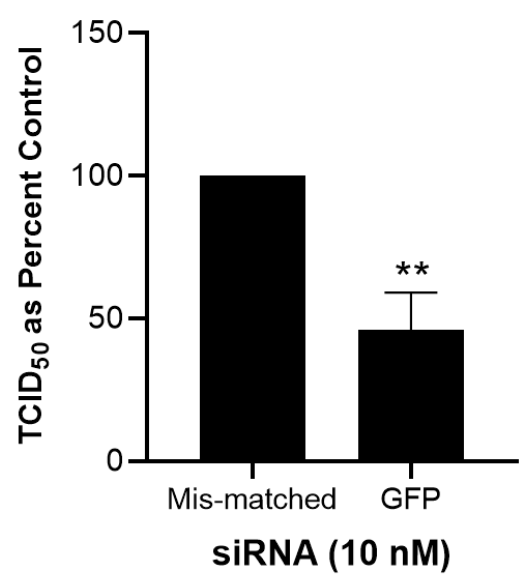

Figure 6 
A.

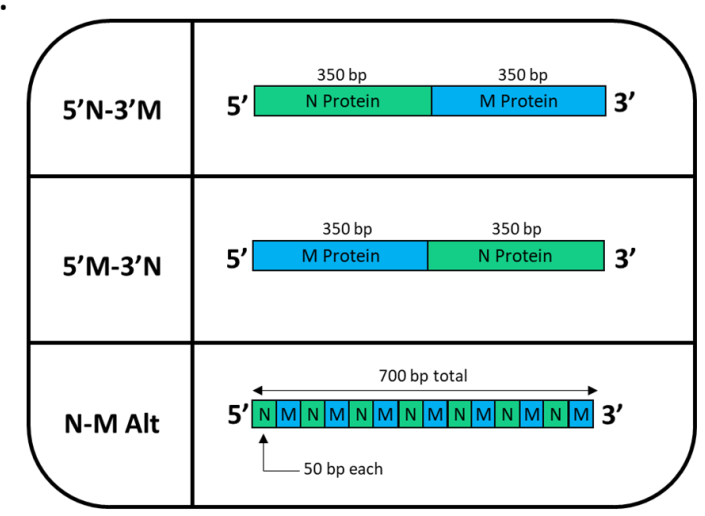

\section{i. VSV Titer}

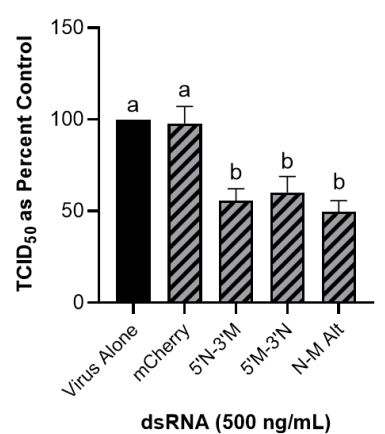

ii. N protein Expression

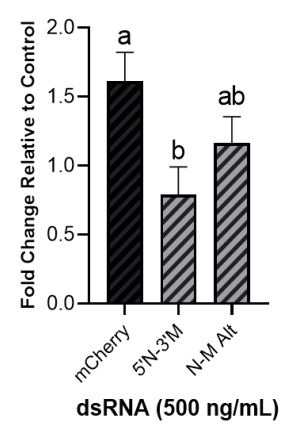

iii. $M$ protein Expression

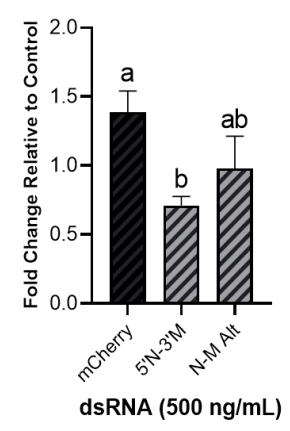

i. VSV Titer

C. $1000 \mathrm{ng} / \mathrm{mL}$

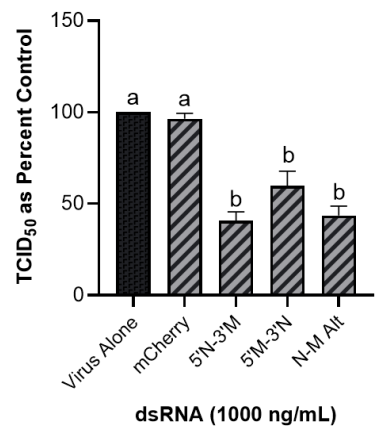

ii. $\boldsymbol{N}$ protein Expression

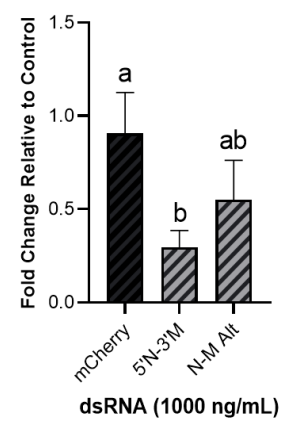

iii. $M$ protein Expression

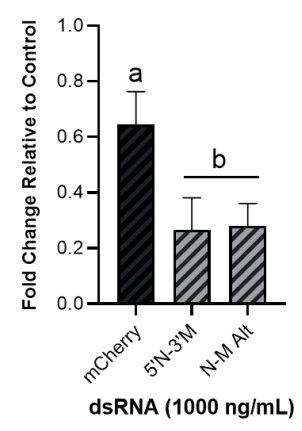




\section{A. Dicer $f / f$}

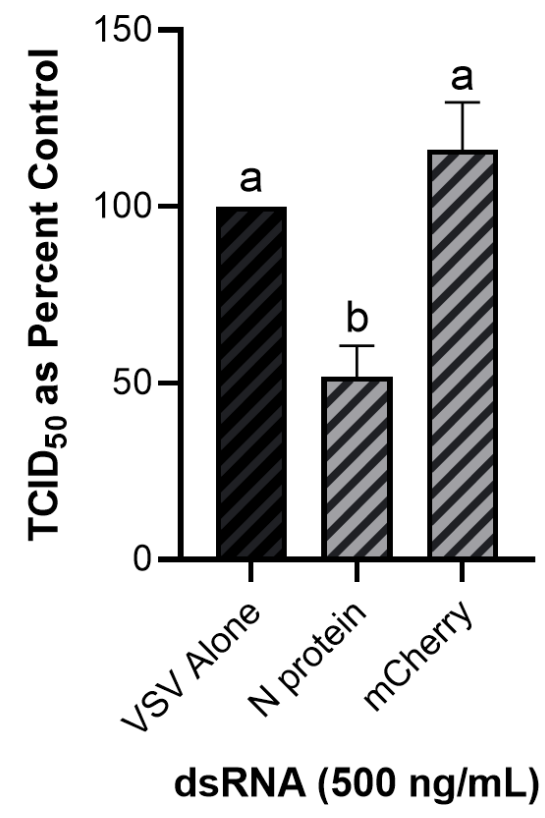

B. Dicer -/-

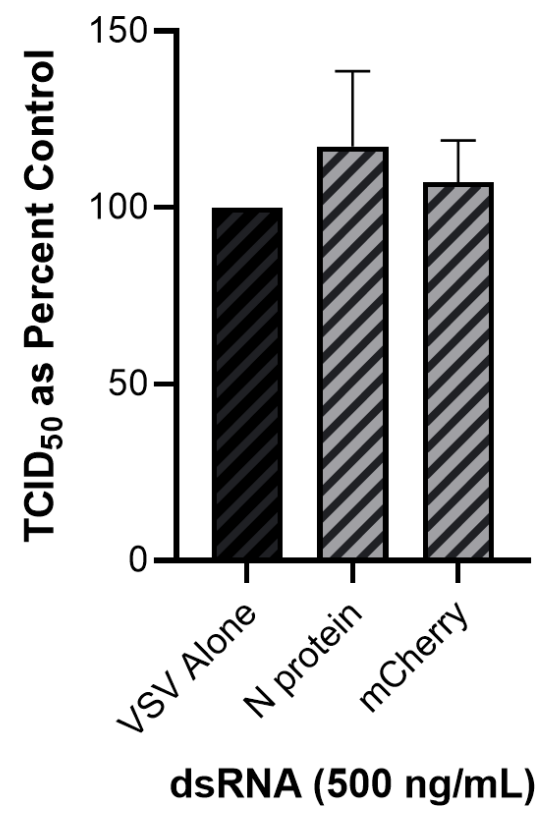

1061

1062

1063 Figure 8

1064

1065

1066 


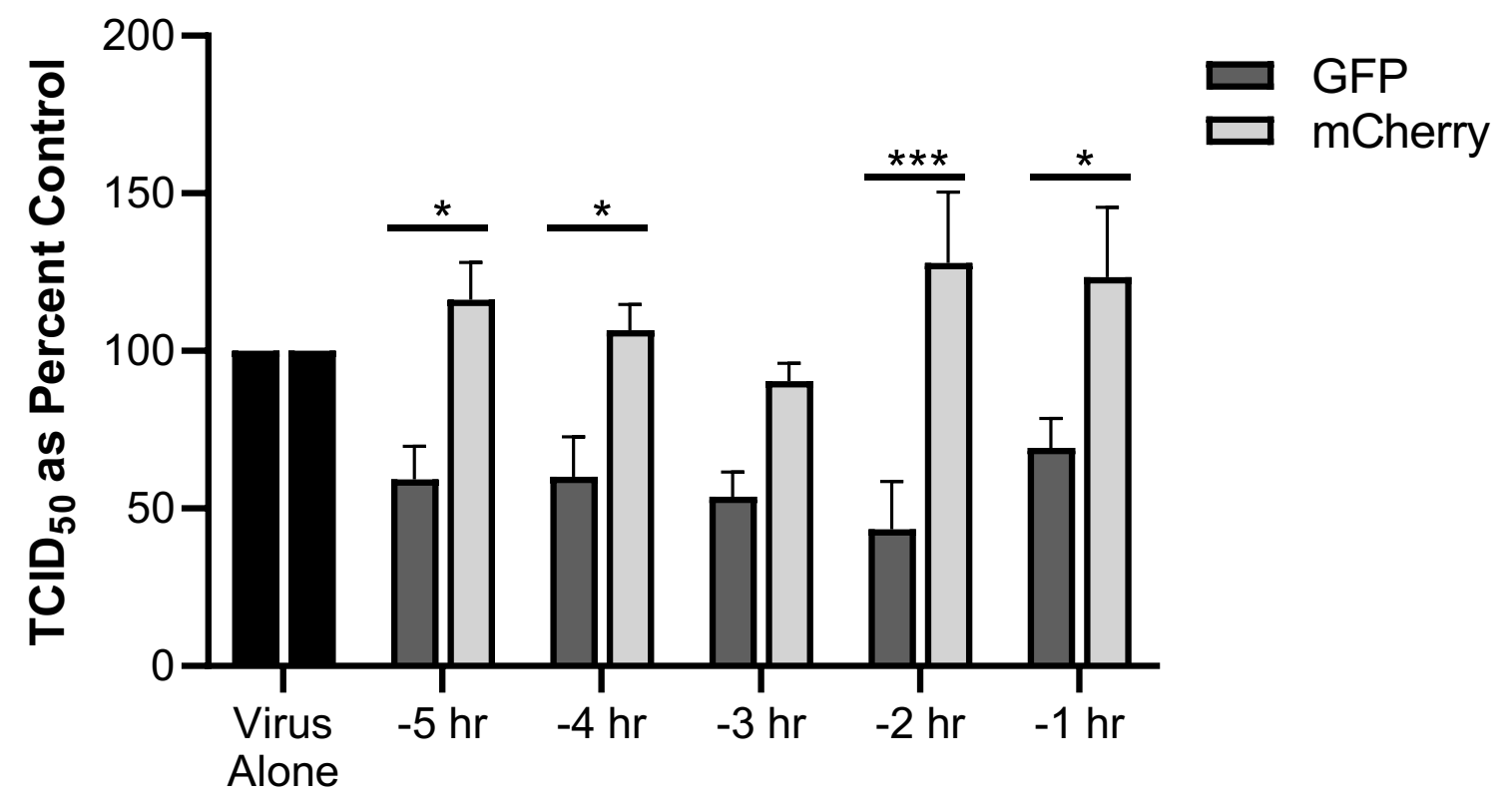

Time exposed to dsRNA (500 $\mathrm{ng} / \mathrm{mL}$ ) before infection

1068

1069

1070

1071

1072

1073

1074

1075

1076
Supplementary Figure S1. dsRNA effective at limiting virus VSV-GFP replication 1-5h prior to infection and at the time of infection.

M14 Cells (75,000 cells/well) were exposed to $500 \mathrm{ng} / \mathrm{mL}$ of each dsRNA (700 bp each) at various times before infection with VSV-GFP (MOI = 1). Following 24 hours of infection, supernatants were collected and the TCID50 was calculated using HEL-299 cells. This has been repeated three times. Significant differences were assessed between mCherry and GFP at each individual timepoint using a Sidak's multiple comparisons test. 